This item was submitted to Loughborough's Research Repository by the author.

Items in Figshare are protected by copyright, with all rights reserved, unless otherwise indicated.

\title{
Organocatalytic synthesis of benzazetidines by trapping hemiaminals with protecting groups
}

\section{PLEASE CITE THE PUBLISHED VERSION}

https://doi.org/10.1021/acs.joc.9b01148

\section{PUBLISHER}

(c) American Chemical Society (ACS)

\section{VERSION}

AM (Accepted Manuscript)

\section{PUBLISHER STATEMENT}

This document is the Accepted Manuscript version of a Published Work that appeared in final form in The Journal of Organic Chemistry, copyright @ American Chemical Society after peer review and technical editing by the publisher. To access the final edited and published work see https://doi.org/10.1021/acs.joc.9b01148.

\section{LICENCE}

CC BY-NC-ND 4.0

\section{REPOSITORY RECORD}

Salvio, Riccardo, Simone Placidi, Arianna Sinibaldi, Antonio Di Sabato, Dario C. Buscemi, Andrea Rossi, Achille Antenucci, Andrei Malkov, and M. Bella. 2019. "Organocatalytic Synthesis of Benzazetidines by Trapping Hemiaminals with Protecting Groups”. Loughborough University. https://hdl.handle.net/2134/37863. 


\title{
Organocatalytic Synthesis of Benzazetidines by Trapping Hemiami- nals with Protecting Groups
}

\author{
Riccardo Salvio, ${ }^{[a][b] * ~ S i m o n e ~ P l a c i d i, ~}{ }^{[a]}$ Arianna Sinibaldi, ${ }^{[a]}$ Antonio Di Sabato, [a] Dario C. \\ Buscemi, ${ }^{[a]}$ Andrea Rossi, ${ }^{[a]}$ Achille Antenucci, ${ }^{[a]}$ Andrei Malkov, ${ }^{[c]}$ Marco Bella ${ }^{[a] *}$
}

[a] Dipartimento di Chimica Sapienza Università di Roma P.le Aldo Moro 5, oo185 Roma, Italy

[b] IMC-CNR Sezione Meccanismi di Reazione, Sapienza Università di Roma, Italy

[c] Department of Chemistry, Loughborough University, UK

KEYWORDS: hemiaminals •benzazetidine $•$ ring strain $•$ strained heterocycles

\begin{abstract}
Benzazetidines are highly strained and inherently unstable heterocycles. There are only few methodologies for assembling these compounds. Here, a protocol is presented to trap an elusive cyclic, 4-membered hemiaminal structure. This method affords several benzazetidine in moderate to good yields (up to 81\%), it uses inexpensive materials and does not require catalysts based on transition metals. The high ring strain energy of these benzazetidine systems was estimated by DFT calculations to be about $32 \mathrm{kcal} \mathrm{mol}^{-1}$. This synthesis can be applied also on gram scale with reaction yield essentially unchanged.
\end{abstract}

\section{-INTRODUCTION}

Hemiaminals are compounds generated by fast and reversible reaction of a carbonyl with an aromatic or aliphatic amine. They are intermediates in the formation of imines, usually highly unstable, and they have been rarely directly observed. ${ }^{1-4}$ In a seminal report by Rebek et al., ${ }^{2}$ the trapping of this intermediate was accomplished in the cavity of a resorcinarene for a duration of time long enough (half-life about 30 minutes) to observe this species by NMR spectroscopy before it undergoes dehydration reaction. In another remarkable example, Fujita and coworkers reported the X-ray analysis of a short-lived hemiaminal entrapped within the pores of a porous coordination network. 3

In the course of our recent research work on the development of new organocatalytic synthetic procedures, 5 we succeeded in reversibly trapping, with the aid of protecting groups, the hemiaminal function affording a benzazetidine scaffold. Benzazetidines are compounds containing a highly strained benzo-fused four-membered azetidine motif.6-9 These small and strained $N$-heterocycles are potentially promising for applications in drug design and biomedical research.7,10 However the synthesis of benzazetidine and their reactivity remain largely unexplored because of the scarcity of effective synthetic methodologies towards this class of compounds ${ }^{6-9,11-13}$ which stems from their relative instability. ${ }^{6,8,14}$ They also attract interest because, in the family of the fused four-membered $N$-heterocycles, the fused $\beta$-lactams account for the largest share of research efforts and, consequently, there is a lack of diversity among these compounds in the literature.

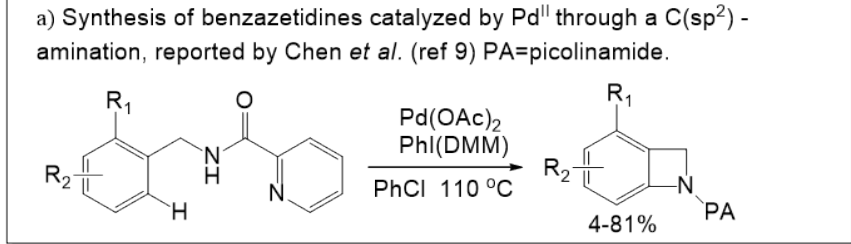

b) Domino $\mathrm{C}\left(\mathrm{sp}^{3}\right)-\mathrm{H}$ arylation catalyzed by $\mathrm{Pd}^{0}$ affording an unstable benzazetidine intermediate which rearranges to a benzoxazine, reported by Baudoin et al. (ref 8 ).

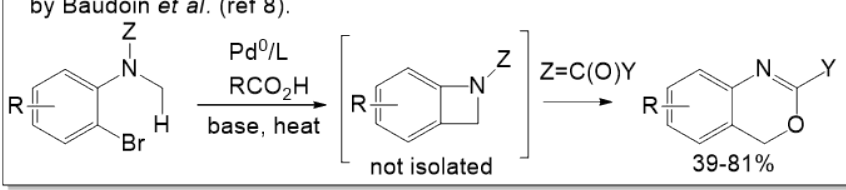

c) This work: DMAP catalyzed four-membered ring closure followed by Boc-protection

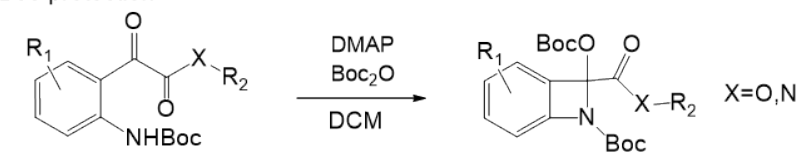

Scheme 1. Recent literature reports about the synthesis of the benzazetidine rings and comparison with the present work.

In 2016 Chen et al. reported the synthesis of benzazetidines by an intramolecular $\mathrm{C}\left(\mathrm{sp}^{2}\right)$ amination accomplished with the use of $\mathrm{Pd}^{\mathrm{II}}$ as catalyst (see Scheme 1a). ${ }^{9}$ In this procedure, the use of phenyliodonium dimethylmalonate (PhI DMM) is crucial because the oxidation of $\mathrm{Pd}^{\mathrm{II}}$ palladacycles with this reagent induces a kinetically controlled pathway to give the strained ring-closed compounds.

Recently, Baudoin and co-workers considered an alternative approach to benzazetidine from 2-bromo- $N$-methyl-anylides via an intramolecular $\mathrm{C}-\left(\mathrm{sp}^{3}\right)-\mathrm{H}$ arylation (Scheme $\left.\mathrm{ib}\right){ }^{8}$ They attempted to synthesize this heterocycle by a method similar 
to that reported for the synthesis of other strained four-membered rings such as $\beta$-lactams ${ }^{15}$ and benzocyclobutenes. ${ }^{16,17}$ However, they were unable to extend this methodology to the synthesis of benzazetidines, mainly because of the instability of this ring system under the high temperature conditions typically required in such reactions. ${ }^{8}$ The four-membered heterocycles initially formed turned out to be unstable and underwent a ring expansion leading to ${ }_{4} \mathrm{H}$-3,1-benzoaxazines (Scheme ib).

\section{- RESULTS AND DISCUSSION}

In the present report, we disclose a novel approach to the synthesis of benzazetidines containing a diprotected hemiaminal fragment, which involves a base-catalyzed intramolecular nucleophilic cyclization of 2-(N-Boc-anilino)- $\alpha$-ketoesters (amides), followed by the in situ protection of the hydroxyl group of thus generated labile cyclic hemiaminal species (Scheme 1c).

In this procedure, we used as starting materials the $1 \mathrm{H}$-indole-2,3-dione (isatin, 1) and its derivatives, which are inexpensive and available on a large-scale from commercial sources (see Scheme 2). Other features of this synthetic route also include the use of operationally simple procedures, mild reaction conditions, the employment of common and inexpensive reagents/catalysts. In contrast to the recently reported methods for the synthesis of benzazetidines, this protocol does not require the use of catalysts based on transition metals. ${ }^{8,9}$<smiles>[R]c1ccc2c(c1)C(=O)C(O[R16]([H])([H])F)N2</smiles><smiles>[R]c1ccc2c(c1)C(=O)C(=O)N2C(=O)OC(C)(C)N</smiles><smiles>[R]c1ccc2c(c1)C(OC(=O)OC(C)(C)C)(C(N)=O)N2C(=O)OC(C)(C)C</smiles><smiles>[R]c1ccc(NC(=O)OC(C)(C)C)c(C(=O)C(N)=O)c1</smiles>

Scheme 2. Synthetic pathway for the synthesis of benzazetidines described in the current work.

Isatins 1 from commercial source (Aldrich, 97-99\%) can be turned in the corresponding $\mathrm{N}$-Boc-protected derivatives 2 by reaction with di-tert-butyl dicarbonate $\left(\mathrm{Boc}_{2} \mathrm{O}\right)$ in the presence of 4-dimethylaminopyridine (DMAP) with a procedure reported in the literature. ${ }^{[18]}$ Upon this substitution we can obtain an inversion of the reactivity order of the carbonyl groups in the heterocyclic compound: in compound $\mathbf{2}$ the most reactive carbonyl toward a nucleophilic attack is the one in position 2, at variance with what is commonly observed in unprotected isatins. ${ }^{[19,20]}$ For this reason, the $N$-Boc-protected isatins $\mathbf{2}$ can undergo the attack of oxygen or nitrogen nucleophiles $(\mathrm{NuH})$, including methyl esters of amino acids, resulting in a ring opening to afford precursor 3 . The last and the most intriguing synthetic step consists in an intramolecular attack of the nitrogen atom onto the carbonyl group with the formation of the highly-strained di-Boc-protected hemiaminal 4. This step can be classified as 4-exo-trig and it is predicted to be favored according to Baldwin's rules. $\left.{ }^{21,22}\right]$

In Table 1 are reported the conditions and the isolated yields of the ring opening reactions of Boc-protected isatins with different substituens on the aromatic ring with a variety of different nucleophiles to afford compounds 3. In the table were reported the reaction conditions that resulted in the best isolated yields. The reactions were carried out using the nucleophile as solvent, as in the case of methanol and ethanol, or using the indicated solvent. The reactions with butylamine and amino acids protected as methyl esters, were carried out in a biphasic mixture of DCM: water as indicated in the Table and described in the Experimental Section. The yields are nearly quantitative in the case of entries 1 and 2, and good in a relevant number of cases.

Table 1. Boc-protected isatin (2) ring opening with the listed nucleophiles to afford compounds $3^{\text {[a] }}$

\begin{tabular}{|c|c|c|c|c|c|c|}
\hline $\begin{array}{l}\text { En- } \\
\text { try }\end{array}$ & $\mathrm{R}_{1}$ & $\mathrm{NuH}$ & $\begin{array}{l}\text { Temp } \\
{\left[{ }^{\circ} \mathrm{C}\right]}\end{array}$ & Solvent & $\begin{array}{l}\text { Yield } \\
\%^{[b]}\end{array}$ & Product \\
\hline 1 & $\mathrm{H}$ & $\mathrm{MeOH}$ & $\mathrm{rt}$ & $\mathrm{MeOH}$ & 99 & $3 a a$ \\
\hline 2 & $\mathrm{H}$ & $\mathrm{EtOH}$ & $\mathrm{rt}$ & $\mathrm{EtOH}$ & 99 & $3 a b$ \\
\hline $3^{[c]}$ & $\mathrm{H}$ & hydroxyacetone & $\mathrm{rt}$ & DCM & 85 & $3 a c$ \\
\hline $4^{[c]}$ & $\mathrm{H}$ & Ethyl glycolate & 4 & DCM & 81 & 3ad \\
\hline $5^{[c]}$ & $\mathrm{H}$ & 2-chloroethanol & $\mathrm{rt}$ & DCM & 78 & zae \\
\hline $6^{[\mathrm{c}]}$ & $\mathrm{H}$ & 2-iodoethanol & 4 & DCM & 50 & 3af \\
\hline $7^{[\mathrm{c}]}$ & $\mathrm{H}$ & 2-propen-1-ol & $\mathrm{rt}$ & DCM & 77 & $3 a g$ \\
\hline $8^{[c]}$ & $\mathrm{H}$ & 3-buten-2-ol & $\mathrm{rt}$ & DCM & 32 & $3 a h$ \\
\hline 9 & $\mathrm{H}$ & butylamine & 4 & biphasic [d] & 80 & 3ai \\
\hline 10 & $\mathrm{Cl}$ & $\mathrm{MeOH}$ & $\mathrm{rt}$ & $\mathrm{MeOH}$ & 58 & $3 \mathbf{b a}$ \\
\hline 11 & $\mathrm{Cl}$ & $\mathrm{EtOH}$ & $\mathrm{rt}$ & $\mathrm{EtOH}$ & 81 & $3 \mathbf{b b}$ \\
\hline $12^{[c]}$ & $\mathrm{Cl}$ & 3-bromo propanol & $\mathrm{rt}$ & DCM & 27 & $3 \mathbf{b j}$ \\
\hline $13^{[c]}$ & $\mathrm{Cl}$ & 3-buten-2-ol & $\mathrm{rt}$ & DCM & 59 & $3 \mathbf{b h}$ \\
\hline $14^{[\mathrm{e}]}$ & $\mathrm{Br}$ & $\mathrm{EtOH}$ & $\mathrm{rt}$ & $\mathrm{EtOH}$ & 45 & $3 \mathbf{c b}$ \\
\hline $15^{[\mathrm{e}]}$ & $\mathrm{Me}$ & $\mathrm{EtOH}$ & $\mathrm{rt}$ & $\mathrm{EtOH}$ & 57 & $3 \mathrm{db}$ \\
\hline $16^{[\mathrm{e}]}$ & $\mathrm{NO}_{2}$ & $\mathrm{EtOH}$ & $\mathrm{rt}$ & $\mathrm{EtOH}$ & 48 & $3 e b$ \\
\hline 17 & $\mathrm{H}$ & $\mathrm{NH}_{2}$-Glicine-OMe & $\mathrm{rt}$ & biphasic [d] & 76 & 3ak \\
\hline 18 & $\mathrm{H}$ & $\begin{array}{l}\mathrm{NH}_{2} \mathrm{~L}- \\
\text { phenylalanine-OMe }\end{array}$ & $e^{r t}$ & biphasic [d] & 86 & 3al \\
\hline 19 & $\mathrm{H}$ & $\mathrm{NH} 2$-L-valine-OMe & $\mathrm{rt}$ & biphasic [d] & 68 & 3am \\
\hline
\end{tabular}

[a] general procedure followed unless differently stated in the notes or in the Supporting Information: $100-200 \mathrm{mg}$ of the Boc-protected isatin was dissolved in 3-5 $\mathrm{mL}$ of the indicated solvent thermostated at rt or 4 ${ }^{\circ} \mathrm{C}$, o.4 eq $\mathrm{Et}_{3} \mathrm{~N}$. In the case $\mathrm{NuH}$ is not $\mathrm{MeOH}$ either $\mathrm{EtOH}, \mathrm{1}^{-3}$ equivalents of the nucleophile were added in a single addition unless otherwise stated (see note [c]). Reaction time: 1-5 h. See Experimental Section and Supporting Information for further details. [b] isolated yield; [c] the nucleophile addition was carried out in a portionwise manner. [d] the reaction was carried out in a 1:1 mixture of DCM and water (o.4 M of Na$\mathrm{HCO}_{3}$ ). There was no evidence of the formation of the $\alpha$-ketocarboxylic acid by nucleophilic attack of the hydroxide ion to compound 2. [e] the protection of the isatin and the ring opening reaction were carried out by a one pot procedure because of the relative lability of the corresponding Boc-protected isatin. [f] the amino acids were employed as methyl esters. 
The cyclization reaction of compound 3 to afford the four-membered benzo-fused system 4 is the crucial step of the preparation. This step is carried out in the presence of ditert-butyl dicarbonate to trap the tetrahedral intermediate generated by the nucleophilic attack of the nitrogen onto the carbonyl group.

Table 2. Screening of the reaction conditions for the cyclization of compound $3 a b$ to afford $4 a b$ in presence of catalysts. ${ }^{[a]}$

En-
try ${ }^{[\mathrm{a}]}$

[a] The reaction was quenched when the TLC analysis revealed no reagent left or the reaction was not proceeding. The cyclic product 4 is easily detectable on TLC because is markedly fluorescent. Catalyst amount: 0.15 eq. Anhydrous conditions affect the reaction yield to a negligible extent. Further details are reported in the Supporting Information. No yield increase was observed using DMAP in combination with other organic bases such as quinine, triethylamine and DBU. [b] isolated yield [c] THF, DCM, chloroform and toluene were tested as solvents [d] no reaction: no product detected in 2 days.

A systematic screening of the reaction conditions was carried out using ethyl ester 3 ab as a model compound. The cyclization has been tested with a number of commonly used bases in organic preparations and organocatalysis: e.g. triethylamine, DBU, Cinchona alkaloids and their derivatives such as quinine (I), quinidine (III) and thiourea II'23 (see Chart in p. $\mathrm{S}_{53}$ ). None of them led to any detectable amount of product in the investigated solvents (note c to Table 2). On the other hand, 4-dimethylaminopyridine (DMAP) turned out to be an effective catalyst (Table 2, entries 2-8). Since other bases investigated did not promote formation of a relevant amount of cyclic product 4 , this may suggest that the formation of Boc-pyridinium ${ }^{24}$ species, as acyl (tert-butoxycarbonyl) transfer agent, plays a crucial role in this process (nucleophilic catalysis). Furthermore, the reaction appears to be sensitive, in terms of isolated yields, to the experimental conditions such as temperature, quantity of $\mathrm{Boc}_{2} \mathrm{O}$, and the nature of the solvent. A possible reason of such a variance is a competitive side-reaction that leads to the formation of the $\mathrm{N}, \mathrm{N}$-di-Boc-protected compound $\mathbf{5}$, which was isolated from most of the crude reaction mixtures by silica gel chromatography.

A number of tests, employing a Design of Experiment (DoE) approach, ${ }^{25}$ were performed to explore the chemical space (see Experimental Section and p. $\mathrm{S}_{53}$ for further details). A representative selection of the experiments is shown in Table 2 . The data indicate that the conditions in entry 3 appear to be the optimum for performing the hemiaminal trapping reaction. It was also noted that the use of anhydrous solvents had only a negligible effect on the yields and the reaction times.

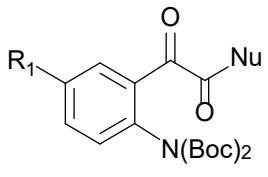

5

The reaction scope was explored by employing several $\alpha$-ketoesters/amides 3 prepared with different combinations of $R_{1}$ and $\mathrm{NuH}$. These benzazetidines 4, shown in Scheme 3, have been synthesized using the optimal conditions as per entry 3 , Table 2, i.e. $15 \%$ mol DMAP, 3.1 eq Boc $_{2} \mathrm{O}$ and $4{ }^{\circ} \mathrm{C}$ in DCM.

The results indicate that the reaction has a reasonably wide scope. The yields are ranging from satisfactory to good; in only few occasions lower yields were observed. Scheme 3 also gives the reaction time in hours. The reactions were stopped upon disappearance of the reagent or whenever the product formation was not proceeding further.

Electron withdrawing substituents in the aromatic ring appear to accelerate the reaction rate, especially in the case of the nitro group. In the preparation of $4 \mathbf{e b}$ from $3 \mathbf{e b}$ the reaction was complete in less than one hour, in contrast with all the other preparative procedure that required longer reaction times. It is likely that the presence of the nitro group facilitates deprotonation of the NH-Boc to allow for an intramolecular attack onto the carbonyl to take place, which results in a shorter reaction time.

Compounds 4 were characterized by ${ }^{1} \mathrm{H}$ and ${ }^{13} \mathrm{C}-\mathrm{NMR}$ and, for $4 \mathbf{a b}$ and 4 ac, also by HMBC and HSQC 2D NMR spectroscopy, that allowed a complete assignment of signals (p. S25-6 and $\mathrm{S}_{2} 8$ in the $\mathrm{SI}$ ). In the ${ }^{13 \mathrm{C}-N M R}$ spectrum of compound $3 \mathrm{ab}$ two signals at $190.3 \mathrm{ppm}$ and $164.0 \mathrm{ppm}$ are clearly visible. They can be assigned to the carbonyl carbon atoms of the ketone and ester function, respectively (p. $\mathrm{S}_{4}$ in the SI). In the ${ }^{13} \mathrm{C}$-NMR spectrum of $\mathbf{4 a b}$ only the carbonyl signal of the ester group was detected, at $167.8 \mathrm{ppm}$; the signal at $96.8 \mathrm{ppm}$ can be justifiably attributed to the hemiaminal carbon atom (p. $\mathrm{S}_{24}$ in $\mathrm{SI}$ ). The ${ }^{1} \mathrm{H}-\mathrm{NMR}$ spectrum is also consistent with the structure $4 \mathbf{a b}$ due to the presence of the signals assignable to the diastereotopic protons of the methylene group (p. S24). On the basis of spectroscopic evidence (see also IR spectra, p. $\mathrm{S}_{52}$ ), we can assign the structure of $4 \mathrm{ab}$ and, by analogy, of the rest of compounds 4 synthesized in the present work, as consisting of the benzo-fused four-membered system. Formation of the alternative five-membered cycle, can be excluded, as this mode of cyclization was observed when different protecting groups in the place of the Boc were used (vide infra). On the basis of UV-Vis spectra, ${ }^{15} \mathrm{~N}$ NMR and GIAO DFT calculations of ${ }^{13} \mathrm{C}$ chemical shifts we could also exclude the assignment of compounds 4 to a 6-membered acetal structure (see SI p. S63-66). 
Purification of compounds 4 by chromatography can be critical because a slow degradation of 4 on the stationary phase (silica, neutral or basic alumina) is taking place during chromatography. For this reason, the purification has to be carried out in the shortest possible time. At the same time, compounds 4 are very stable if stored as oils or as solutions in methanol, DCM or ethyl acetate (no degradation was observed in 2 weeks).

As expected from the presence of the Boc units, benzazetidines 4 are sensitive to the presence of acids. The two Boc units are not equivalent since one of them is a carbonate while the another is a carbamate. Their different reactivity can be exploited to selectively remove one of the protective group.

Scheme 3. Scope of the DMAP-catalyzed preparation of benzazetidines 4 from acyclic precursors 3 . The reactions were performed employing the optimized conditions (see Table 2 , entry 3 ). The reaction time in hours is reported below.

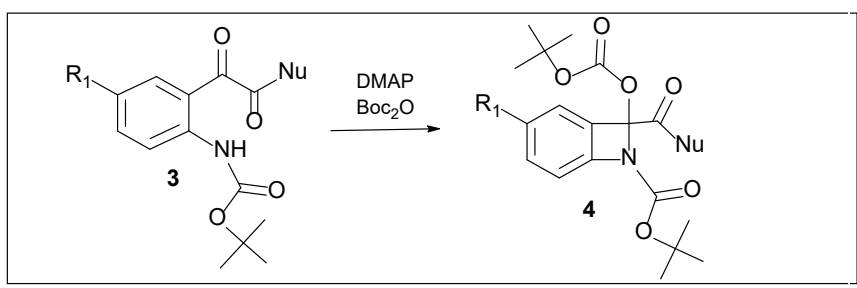

(c)

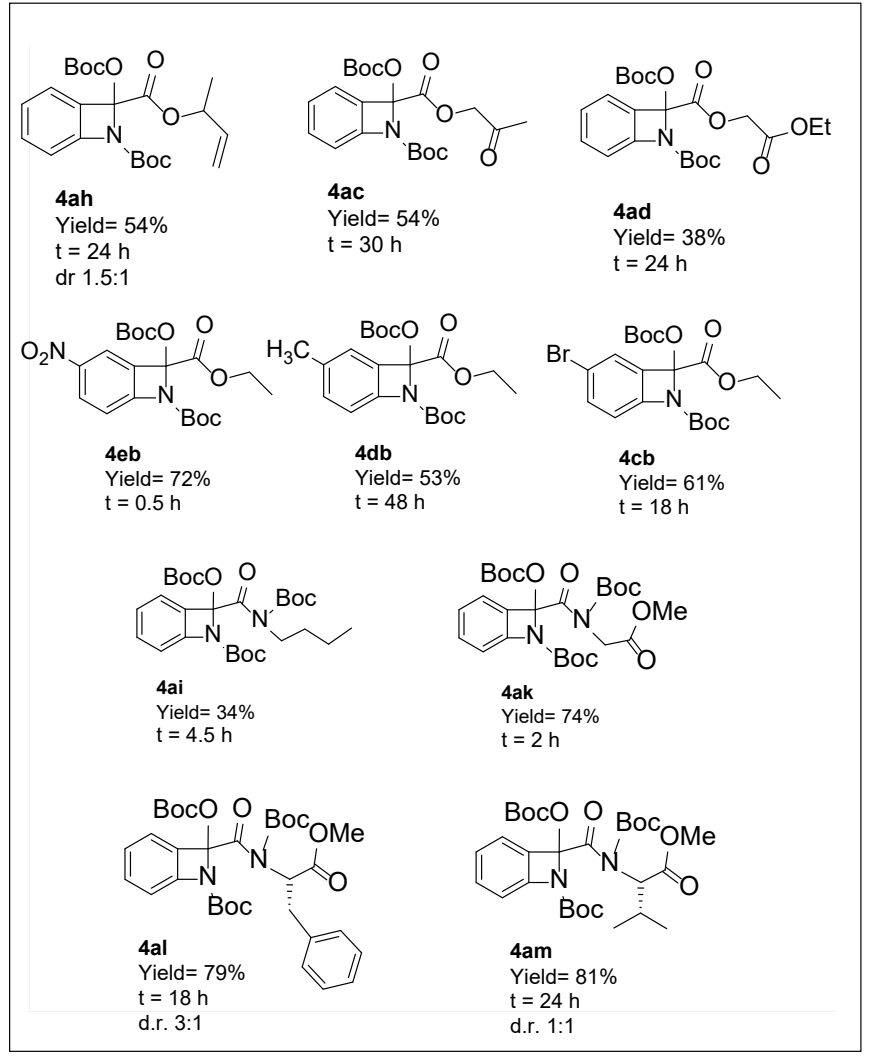

Small amount of $\mathrm{HClO}_{4}$ in DCM (o.1 molar equivalents) rapidly cleave the carbonate converting the protected hemiaminal $4 \mathbf{a b}$ into the corresponding acyclic precursor $3 \mathbf{a b}$. The other protecting unit can be removed with trifluoroacetic acid in DCM (1.1 eq, 2h) to afford the starting material isatins $\mathbf{1}$. In order to explore the possibility to obtain the benzazetidine scaffold with different protective motifs, precursors $\mathbf{6}$ and 7 were synthesized by reaction with $p$-toluenesulfonyl chloride and with benzyl chloroformate, respectively. Dicarbonyl compound 6 was treated with different combinations of bases and protective reagents, i.e. $\mathrm{Boc}_{2} \mathrm{O}$, acetic anhydride, acetyl chloride, benzoic anhydride, $t$-butyldimethylsilyl chloride. In none of the attempts any amount of bicyclic product has been detected, except for the case when $\mathrm{Boc}_{2} \mathrm{O}$ was used in the presence of quinine (Scheme 4 ). This reagent/catalyst combination afforded the $\mathrm{N}$-Boc protected derivative $\mathbf{6}^{\prime}$, as major product and, surprisingly, small quantities of five-membered cyclic product $\mathbf{8}$, which could be isolated from the reaction mixture as a pure compound ( $4 \%$ yield, p. $\mathrm{S}_{4} 8$ ).

Chemical behaviour of the Cbz-protected derivative 7 was explored in a number of reactions. The reaction with $\mathrm{Boc}_{2} \mathrm{O}$ and DMAP afforded only the $\mathrm{N}$-Boc protected derivative with no detectable amount of bicyclic product, whereas the reaction in the presence of $t$-butyldimethylsilyl chloride (TBDMSCl) and 2,6-lutidine as a catalyst resulted in the formation of the five-membered heterocycle 9 in $43 \%$ yield (Scheme 4 ). 


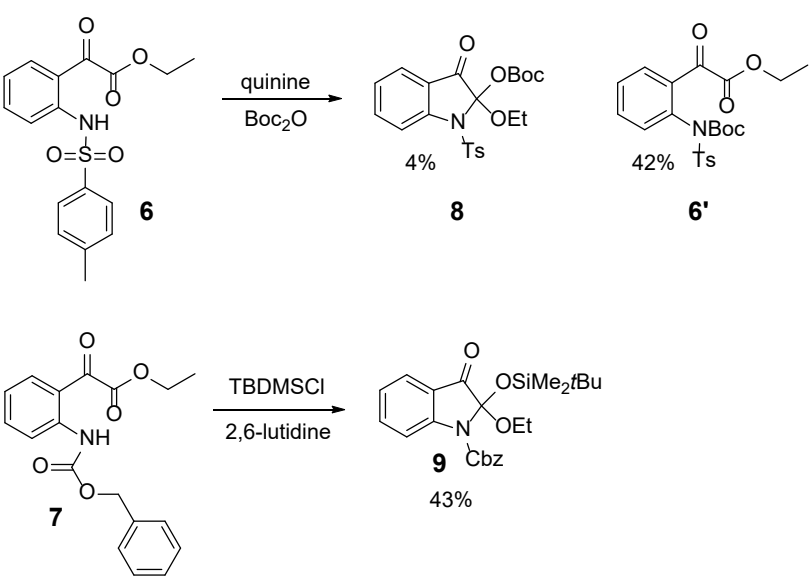

Scheme 4. Ring closing reactions of $N$-tosyl and $N$-Cbz protected aniline $\alpha$-ketoesters.

Compounds 8 and $\mathbf{9}$ were fully characterized by mass spectrometry and conventional and 2D NMR techniques (p. $\mathrm{S}_{4} 8$ 51). The ${ }^{13} \mathrm{C}$ NMR spectra of 8 and 9 clearly indicate the presence of a carbonyl group at 193.2 and $194.1 \mathrm{ppm}$, respectively, that are consistent with the structures containing the five-membered ring and exclude the formation of the four-membered ring (in contrast, compounds 4 typically showed the signals of an ester in the area of 160-180 ppm).

To illustrate the robustness of our preparative procedure a gram-scale synthesis of compound 4 ab was carried out: starting from $1.80 \mathrm{~g}$ ( $5.18 \mathrm{mmol})$ of dicarbonyl compound zab under the optimized conditions (Table 2, entry 3), 4 ab was obtained after chromatography in $57 \%$ yield.

In order to evaluate the ring strain of $\mathbf{4 a b}$, we carried out DFT calculation with the Gaussian o9 package ${ }^{26}$ at b3lyp/6$31 \mathrm{~g}(\mathrm{~d}, \mathrm{p}) / / \mathrm{b} 3 \mathrm{lyp} / 6-3 \mathrm{~g}(\mathrm{~d}, \mathrm{p})$ level of theory, (see Experimental Section and p. S55-6o). The calculations consisted in the determination of the differences of energy, corrected for the zero-point vibrational energy, in a homodesmotic reaction ${ }^{27}$ based on an intermolecular reaction taken as model (see Scheme 5).

An homodesmotic reaction in a real or hypothetical chemical reaction in which the type of chemical bonds broken in the reactant are the same as the type of bonds formed in the reaction product, taking in consideration also the states of hybridization of the atoms. This type of reaction is often used as a hypothetical in computational thermochemistry to increase the accuracy of the calculations. ${ }^{27}$ The reaction in Scheme 5 can be taken as a measurement of the ring strain that is independent on the chemical transformation taking place in the cyclization.

The calculations indicated a strain energy for the four-membered ring of $\mathbf{4} \mathbf{a b}$ as high as $32.7 \mathrm{kcal} \mathrm{mol}^{-1}$. It is meaningful to compare this value with those of other analogous strained systems such as azetidine $\left(23-27 \mathrm{kcal} \mathrm{mol}^{-1}\right){ }^{28}$ and cyclobutane $\left(26,5 \mathrm{kcal} \mathrm{mol}^{-1}\right)$ that are significantly lower than the value obtained in this calculations. This data overcomes even the value of strain energy of cyclopropane $\left(27.5 \mathrm{kcal} \mathrm{mol}^{-1}\right), 22$ probably because of the presence of two $\mathrm{sp}^{2}$ carbon atoms in the ring of 4, which generate a further destabilization of the cyclic species. This destabilization is probably attributable to the higher natural angle of $120^{\circ}$ of this carbon atoms compared to tetrahedral $\mathrm{sp}^{3}$ carbons.

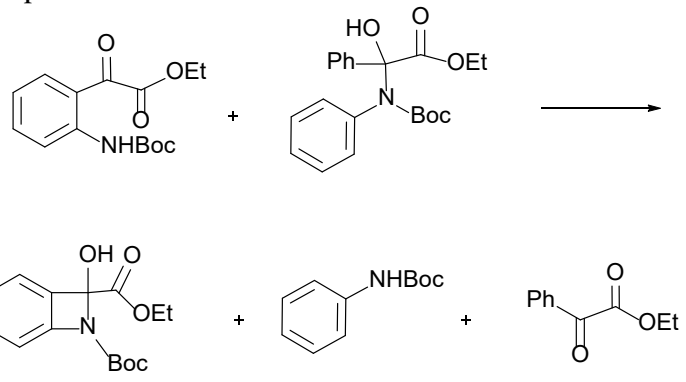

Scheme 5. Homodesmotic reaction used to evaluate the ring strain energy of benzazetidine $4 \mathrm{ab}$.

\section{-CONCLUSIONS}

In conclusion, we have developed a new method for trapping and isolating chemical compounds containing the labile hemiaminal functional group. This procedure affords Boc-protected heterocycles featuring a highly strained benzazetidine motif. We believe that the peculiarity of this reaction and the simplicity of the method, which employs cheap and commercially available starting materials /reagents/ catalysts, coupled with the scarcity of existing synthetic methodologies to prepare this type of heterocycles should render this procedure interesting for the scientific community. Furthermore, the presence of a stereocenter in these molecules opens up avenues for developing an asymmetric version of the reaction.

\section{口EXPERIMENTAL SECTION}

General informations. All analytical and technical grade solvents were used as received. All commercially available reagents and catalysts were used as received. $N$-Boc isatins $2 \mathbf{a}$, $\mathbf{2 b}^{18}$ and $N$-CBz isatin ${ }^{18 b}$ were prepared according to literature procedures. ${ }^{1} \mathrm{H}-\mathrm{NMR}$ and ${ }^{13} \mathrm{C}-\mathrm{NMR}\left\{{ }_{1} \mathrm{H}\right\}$ spectra were recorded on Bruker spectrometers at $300 \mathrm{MHz}$ and $75 \mathrm{MHz}$ or at 400 $\mathrm{MHz}$ and $101 \mathrm{MHz}$ respectively. The ${ }^{15} \mathrm{~N}$ NMR spectrum was recorded with the Bruker $400 \mathrm{MHz}$. Chemical shifts are reported in ppm relative to the resonance of $\mathrm{CDCl}_{3}(\delta=7.26)$ for ${ }^{1} \mathrm{H}$ NMR and to the central peak of $\mathrm{CDCl}_{3}(\delta=77.3)$ for ${ }^{13} \mathrm{C} N M R\{1 \mathrm{H}\}$. The multiplicity is abbreviated as follows: s (singlet), d (doublet), t (triplet), q (quartet), p (quintet), m (multiplet). The coupling constant $\mathrm{J}$ is given in $\mathrm{Hz}$ (Hertz). Flash chromatography (FC) was carried out using Merck silica gel 6o (230-400 mesh) employing mixtures of hexane/ethyl acetate or dichloromethane as eluants.High resolution mass spectrometry was performed on Micromass Q-Tof micro instrument.

Computational details. The DFT calculations were carried out using the Gaussian o9 D package. ${ }^{26}$ The ring strain has been evaluated by the difference of the energies calculated for the molecules in the homodesmotic ${ }^{27}$ reaction in Scheme 5. 
The calculations were performed at the b3lyp/6$3 \lg (\mathrm{d}, \mathrm{p}) / / \mathrm{b} 3 \mathrm{lyp} / 6-3 \mathrm{~g}(\mathrm{~d}, \mathrm{p})$ level of theory. The optimization of the structures was carried out in cartesian coordinates. The calcfc option has been used in the optimization procedure, i.e. $\mathrm{opt}=($ cartesian, calcfc). The polarized continuum model was used to take into account the solvent effect. The solvent parameters were set by using the following keyword and options: $\mathrm{scrf}=(\mathrm{pcm}$,solvent $=\mathrm{dcm})$. The values were corrected for the zero-point-energy. The GIAO DFT calculations were carried out at b3lyp/6-31g (d,p)//b3lyp/6-311+(d,p) level of theory. The following option was used: $\mathrm{scrf}=($ solvent=chloroform, $\mathrm{pcm}$ ). The energies and the coordinates of the DFT calculations are reported in the Supporting Informations p. S55 and following.

Design of Experiments. The DoE was performed by applying a screening design to evaluate the main parameters and their influence on the reaction. The variables selected were: 1) equivalents of $\mathrm{Boc}_{2} \mathrm{O}$ (continuous variable in the range 1.2-5 equiv); 2) amount of catalyst (a continuous variable in the range $5-25 \mathrm{~mol} \%$ ); 3 ) temperature (continuous variable in the range $-20-25^{\circ} \mathrm{C}$ ). The response we desired to optimize was the yield of compound $4 \mathrm{ab}$. The use of a screening design allowed the number of experiments to be reduced. To generate a design we used the custom design function in the software MODDE ${ }^{\circ}$. The design we generated required 15 experiments, the order of which was randomized (See SI, Table S3.1).

\section{Procedures for the synthesis of compounds 3}

Synthesis of 2-( $N$-Boc-anilino)- $\alpha$-ketoesters zaa-zab, 3 ba3 bh. $300 \mathrm{mg}$ of the $\mathrm{N}$-Boc-isatin ( $1.21 \mathrm{mmol}$, 1 equiv) were suspended in $\mathrm{EtOH}$ ( $3.5 \mathrm{~mL}, 60.7 \mathrm{mmol}$, 50 equiv) or $\mathrm{MeOH}(2.5$ $\mathrm{mL}, 60.7 \mathrm{mmol}$, 50 equiv), then $67.5 \mu \mathrm{L}$ of $\mathrm{Et}_{3} \mathrm{~N}$ (0.486 mmol, $40 \mathrm{~mol} \%)$ was added. The reaction mixture was stirred at room temperature for $30 \mathrm{~min}$, then the solvent was evaporated at reduced pressure to afford the product as a yellow oil. The product was used without further purification.

Methyl 2-(2-((Boc)amino)phenyl)-2-oxoacetate (3aa). $334 \mathrm{mg}$ (1.20 mmol), $99 \%$ yield. ${ }^{1} \mathrm{H}$ NMR $\left(300 \mathrm{MHz}, \mathrm{CDCl}_{3}\right) \delta 10.37(\mathrm{~s}$, $1 \mathrm{H}), 8.52(\mathrm{~d}, J=8.5 \mathrm{~Hz}, 1 \mathrm{H}), 7.7 \mathrm{o}-7.49(\mathrm{~m}, 2 \mathrm{H}), 7.07-7.02(\mathrm{~m}$, $1 \mathrm{H}), 3.97(\mathrm{~s}, 3 \mathrm{H}), 1.53(\mathrm{~s}, 9 \mathrm{H}) .{ }^{13 \mathrm{C}} \mathrm{NMR}\left(101 \mathrm{MHz}, \mathrm{CDCl}_{3}\right) \delta$ 190.2, 164.5, 153.1, 144.1, 137.3, 133.9, 121.7, 119.6, 117.0, 81.6, 53.3, 28.6. HRMS (ESI): calcd for $\mathrm{C}_{14} \mathrm{H}_{17} \mathrm{NO}_{5} \mathrm{Na}[\mathrm{M}+\mathrm{Na}]^{+} 302.1004$; found 302.0992.

Ethyl 2-(2-((Boc)amino)phenyl)-2-oxoacetate (3ab). $351 \mathrm{mg}$ (1.20 mmol), $99 \%$ yield. ${ }^{1} \mathrm{H}$ NMR $\left(400 \mathrm{MHz}, \mathrm{CDCl}_{3}\right) \delta 10.39$ (s, $1 \mathrm{H}), 8.50(\mathrm{~d}, J=8.6 \mathrm{~Hz}, 1 \mathrm{H}), 7.7 \mathrm{O}-7.45(\mathrm{~m}, 2 \mathrm{H}), 7.03(\mathrm{t}, J=7.6$ $\mathrm{Hz}, 1 \mathrm{H}), 4.43(\mathrm{q}, J=7.1 \mathrm{~Hz}, 2 \mathrm{H}), 1.51(\mathrm{~s}, 9 \mathrm{H}), 1.39(\mathrm{t}, J=7.1 \mathrm{~Hz}$, 3H). ${ }^{13} \mathrm{C}$ NMR (101 MHz, $\left.\mathrm{CDCl}_{3}\right) \delta 190.3,164.0,152.9,143.9$, 137.0, 133.7, 121.5, 119.4, 116.9, 81.4, 62.7, 28.5, 14.3. HRMS (ESI): calcd for $\mathrm{C}_{15} \mathrm{H}_{19} \mathrm{NO}_{5} \mathrm{Na}[\mathrm{M}+\mathrm{Na}]^{+}$316.1161; found 316.1141.

Methyl 2-(2-((Boc)amino)-5-clhorophenyl)-2-oxoacetate (3ba). $193 \mathrm{mg}$ ( $0.615 \mathrm{mmol}), 58 \%$ yield. FC performed with a mixture of Hexane/Ethyl Acetate as eluant in ratio 20:1. ${ }^{1} \mathrm{H}$ NMR (300 $\left.\mathrm{MHz}, \mathrm{CDCl}_{3}\right) \delta 10.25(\mathrm{~s}, 1 \mathrm{H}), 8.48(\mathrm{~d}, \mathrm{~J}=9.2 \mathrm{~Hz}, \mathrm{1H}), 7.59(\mathrm{~d}, \mathrm{~J}$ $=2.5 \mathrm{~Hz}, 1 \mathrm{H}), 7.5 \mathrm{O}(\mathrm{dd}, \mathrm{J}=9.2,2.5 \mathrm{~Hz}, 1 \mathrm{H}), 3.97(\mathrm{~s}, 3 \mathrm{H}), 1.5 \mathrm{O}(\mathrm{s}$, ${ }_{9 H}$ ). ${ }^{13} \mathrm{C} \mathrm{NMR}\left(75 \mathrm{MHz}, \mathrm{CDCl}_{3}\right) \delta 188.7,163.6,152.6,142.4,136.9$, 132.6, 126.5, 121.0, 117.8, 81.8, 53.4, 28.4. HRMS (ESI): calcd for $\mathrm{C}_{14} \mathrm{H}_{16} \mathrm{ClNO}_{5} \mathrm{Na}[\mathrm{M}+\mathrm{Na}]^{+} 336.0615$; found 336.0638 .

Ethyl 2-(2-((Boc)amino)-5-chlorophenyl)-2-oxoacetate (3bb). $281 \mathrm{mg}$ (0.859 mmol), $81 \%$ yield. FC performed with Dichloromethane as eluant. ${ }^{\mathrm{H}} \mathrm{NMR}\left(4 \mathrm{Oo} \mathrm{MHz}, \mathrm{CDCl}_{3}\right) \delta 10.30(\mathrm{~s}, 1 \mathrm{H})$, $8.50(\mathrm{~d}, \mathrm{~J}=9.2 \mathrm{~Hz}, 1 \mathrm{H}), 7.63(\mathrm{~d}, \mathrm{~J}=2.5 \mathrm{~Hz}, 1 \mathrm{H}), 7.57-7.48(\mathrm{~m}$, $1 \mathrm{H}), 4.45(\mathrm{q}, \mathrm{J}=7.1 \mathrm{~Hz}, 2 \mathrm{H}), 1.51(\mathrm{~s}, 9 \mathrm{H}), 1.41(\mathrm{t}, \mathrm{J}=7.1 \mathrm{~Hz}, 3 \mathrm{H})$. ${ }^{13} \mathrm{C}$ NMR (101 MHz, $\mathrm{CDCl}_{3}$ ) $\delta 189.1,163.3,152.7,142.5,136.9$, 132.7, 126.5, 121.1, 117.9, 81.8, 63.1, 28.5, 14.3. HRMS (ESI): calcd for $\mathrm{C}_{15} \mathrm{H}_{18} \mathrm{ClNO}_{5} \mathrm{Na}[\mathrm{M}+\mathrm{Na}]^{+} 350.0771$; found 350.0756 .

Synthesis of $2-(N$-Boc-anilino)- $\alpha$-ketoesters zac-zaj, $3 \mathbf{b j}$. To a solution of N-Boc-isatin (300 mg, $1.21 \mathrm{mmol}, 1$ equiv) and $\mathrm{Et}_{3} \mathrm{~N}(67.5 \mu \mathrm{L}, 0.486 \mathrm{mmol}, 4 \mathrm{O} \mathrm{mol} \mathrm{\% )}$ in dichloromethane (2 $\mathrm{mL}$ ) was added the nucleophile ( $85-125 \mu \mathrm{L}, 1.21 \mathrm{mmol}$, 1 equiv) in 5 portions of $17-25 \mu \mathrm{L}$ (0.242 mmol, o.2 equiv) each, every $30 \mathrm{~min}$. The reaction mixture was stirred at room temperature for 12 more hours, then purified with flash silica chromatography using dichloromethane or mixtures of hexane and ethyl acetate as eluant. The products are obtained as sticky pale yellow oils.

2-oxopropyl 2-(2-((Boc)amino)phenyl)-2-oxoacetate (3ac). 330 $\mathrm{mg}(1.03 \mathrm{mmol}), 85 \%$ yield. FC performed with a mixture of Hexane/Ethyl Acetate as eluant in gradient from 10:1 to 5:1. ${ }^{1} \mathrm{H}$ NMR (300 MHz, $\left.\mathrm{CDCl}_{3}\right) \delta 10.35(\mathrm{~s}, 1 \mathrm{H}), 8.52(\mathrm{~d}, \mathrm{~J}=8.6 \mathrm{~Hz}, \mathrm{H})$, $8.07(\mathrm{dd}, \mathrm{J}=8.0,1.4 \mathrm{~Hz}, 1 \mathrm{H}), 7.71-7.52(\mathrm{~m}, 1 \mathrm{H}), 7.19-7.03(\mathrm{~m}$, $1 \mathrm{H}), 4.95(\mathrm{~s}, 2 \mathrm{H}), 2.26(\mathrm{~s}, 3 \mathrm{H}), 1.53(\mathrm{~s}, 9 \mathrm{H}) .{ }^{13} \mathrm{C}$ NMR (101 MHz, $\left(\mathrm{CDCl}_{3}\right) \delta 199.8,189.5,163.1,152.8,143.9,137.4,134.6,121.8$, 119.2, 116.95, 81.4, 69.5, 28.5, 26.1. HRMS (ESI): calcd for $\mathrm{C}_{16} \mathrm{H}_{19} \mathrm{NO}_{6} \mathrm{Na}[\mathrm{M}+\mathrm{Na}]^{+}$344.1110; found 344.1138.

2-ethoxy-2-oxoethyl 2-(2-((Boc)amino)phenyl)-2-oxoacetate (3ad). $344 \mathrm{mg}$ ( $0.980 \mathrm{mmol}), 81 \%$ yield. FC performed with a mixture of Hexane/Ethyl Acetate as eluant in ratio 10:1. ${ }^{1} \mathrm{H}$ $\operatorname{NMR}\left(400 \mathrm{MHz}, \mathrm{CDCl}_{3}\right) \delta 10.34(\mathrm{~s}, 1 \mathrm{H}), 8.51(\mathrm{~d}, \mathrm{~J}=8.6 \mathrm{~Hz}, \mathrm{HH})$, $7.99(\mathrm{dd}, \mathrm{J}=8.0,1.4 \mathrm{~Hz}, 1 \mathrm{H}), 7.64-7.51(\mathrm{~m}, 1 \mathrm{H}), 7.16-6.94(\mathrm{~m}$, $1 \mathrm{H}), 4.86(\mathrm{~s}, 2 \mathrm{H}), 4.29(\mathrm{q}, \mathrm{J}=7.1 \mathrm{~Hz}, 2 \mathrm{H}), 1.52(\mathrm{~s}, 9 \mathrm{H}), 1.32(\mathrm{t}, \mathrm{J}$ $\left.=7.2 \mathrm{~Hz},{ }_{3} \mathrm{H}\right) .{ }^{13 \mathrm{C}} \mathrm{NMR}\left(101 \mathrm{MHz}, \mathrm{CDCl}_{3}\right) \delta 189.5,167.1,163.5$, 153.0, 144.1, 137.5, 134.7, 121.9, 119.4, 117.1, 81.6, 62.4, 62.1, 28.7, 14.5. HRMS (ESI): calcd for $\mathrm{C}_{14} \mathrm{H}_{17} \mathrm{NO}_{5} \mathrm{Na}$ [M$\left.\mathrm{OCH}_{2} \mathrm{COOEt}+\mathrm{OCH}_{3}+\mathrm{Na}\right]^{+} 302.1004$; found 302.0987

2-chloroethyl 2-(2-((Boc)amino)phenyl)-2-oxoacetate (3ae). $308 \mathrm{mg}$ (o.944 mmol), $78 \%$ yield. FC performed with Dichloromethane as eluant. ${ }^{1} \mathrm{H}$ NMR $\left(300 \mathrm{MHz}, \mathrm{CDCl}_{3}\right) \delta 10.35$ $(\mathrm{s}, 1 \mathrm{H}), 8.50(\mathrm{~d}, \mathrm{~J}=8.4 \mathrm{~Hz}, 1 \mathrm{H}), 7.67(\mathrm{dd}, \mathrm{J}=8.0,1.4 \mathrm{~Hz}, 1 \mathrm{H})$, $7.65-7.56(\mathrm{~m}, 1 \mathrm{H}), 7.09-7.01(\mathrm{~m}, 1 \mathrm{H}), 4.67-4.60(\mathrm{~m}, 2 \mathrm{H})$, $3.83-3.77(\mathrm{~m}, 2 \mathrm{H}), 1.51(\mathrm{~s}, 9 \mathrm{H}) .{ }^{13 \mathrm{C} N M R}\left(75 \mathrm{MHz}, \mathrm{CDCl}_{3}\right) \delta$ 189.4, 163.4, 152.8, 144.0, 137.3, 133.8, 121.5, 119.3, 116.6, 81.4, 65.6, 41.3, 28.4. HRMS (ESI): calcd for $\mathrm{C}_{14} \mathrm{H}_{17} \mathrm{NO}_{5} \mathrm{Na}$ [M$\left.\mathrm{O}\left(\mathrm{CH}_{2}\right)_{2} \mathrm{Cl}+\mathrm{OCH}_{3}+\mathrm{Na}\right]^{+}$302.1004; found 302.0982

2-iodoethyl 2-(2-((Boc)amino)phenyl)-2-oxoacetate (3af).

$253 \mathrm{mg}$ ( $0.605 \mathrm{mmol}), 50 \%$ yield. FC performed with a mixture of Hexane/Ethyl Acetate as eluant in ratio 10:1. ${ }^{1} \mathrm{H}$ NMR (400 $\left.\mathrm{MHz}, \mathrm{CDCl}_{3}\right) \delta 10.33(\mathrm{~s}, 1 \mathrm{H}), 8.50(\mathrm{~d}, \mathrm{~J}=8.6 \mathrm{~Hz}, 1 \mathrm{H}), 7.67(\mathrm{dd}, \mathrm{J}$ $=8.0,1.3 \mathrm{~Hz}, 1 \mathrm{H}), 7.63-7.55(\mathrm{~m}, \mathrm{lH}), 7.08-7.00(\mathrm{~m}, 1 \mathrm{H}), 4.62$ $(\mathrm{t}, \mathrm{J}=6.8 \mathrm{~Hz}, 2 \mathrm{H}), 3.39(\mathrm{t}, \mathrm{J}=6.8 \mathrm{~Hz}, 2 \mathrm{H}), 1.51(\mathrm{~s}, 9 \mathrm{H}) .{ }^{13} \mathrm{C}$ NMR $\left(101 \mathrm{MHz}, \mathrm{CDCl}_{3}\right) \delta 189.3,163.1,152.7,143.9,137.2,133.9,121.5$, 119.3, 116.6, 81.4, 66.3, 28.4, -1.1. HRMS (ESI): calcd for $\mathrm{C}_{14} \mathrm{H}_{17} \mathrm{NO}_{5} \mathrm{Na} \quad\left[\mathrm{M}-\mathrm{O}\left(\mathrm{CH}_{2}\right)_{2} \mathrm{I}+\mathrm{OCH}_{3}+\mathrm{Na}\right]^{+} \quad 302.1004 ;$ found 302.0979.

Allyl 2-(2-((Boc)amino)phenyl)-2-oxoacetate (3ag). $284 \mathrm{mg}$ (o.932 mmol), $77 \%$ yield. FC performed with Dichloromethane as eluant. ${ }^{1} \mathrm{H}$ NMR $\left(400 \mathrm{MHz}, \mathrm{CDCl}_{3}\right) \delta 10.39(\mathrm{~s}, 1 \mathrm{H})$, $8.52(\mathrm{~d}, \mathrm{~J}=8.3 \mathrm{~Hz}, 1 \mathrm{H}), 7.73-7.46(\mathrm{~m}, 2 \mathrm{H}), 7.16-6.87(\mathrm{~m}, \mathrm{lH})$, 6.00 (ddt, $J=16.3,10.4,5.9 \mathrm{~Hz}, 1 \mathrm{H}$ ), 5.45 (ddd, $J=17.2,2.6,1.3$ $\mathrm{Hz}, 1 \mathrm{H}), 5.35(\mathrm{dd}, \mathrm{J}=10.4,1.1 \mathrm{~Hz}, 1 \mathrm{H}), 4.87(\mathrm{dt}, \mathrm{J}=5.9,1.2 \mathrm{~Hz}$, $\left.{ }_{2 \mathrm{H}}\right),{ }_{1.52}(\mathrm{~s}, 9 \mathrm{H}) .{ }^{13 \mathrm{C}} \mathrm{NMR}\left(101 \mathrm{MHz}, \mathrm{CDCl}_{3}\right) \delta$ 190.0, 163.7, 153.0, 144.0, 137.2, 133.8, 130.9, 121.6, 120.5, 119.5, 116.9, 81.5, 67.0, 
28.5. HRMS (ESI): calcd for $\mathrm{C}_{14} \mathrm{H}_{17} \mathrm{NO}_{5} \mathrm{Na}$

$[\mathrm{M}-$ $\left.\mathrm{OCH}_{2} \mathrm{CH}=\mathrm{CH}_{2}+\mathrm{OCH}_{3}+\mathrm{Na}\right]^{+}$302.1004; found 302.1009.

But-3-en-2-yl 2-(2-((Boc)amino)phenyl)-2-oxoacetate (3ah). 137 $\mathrm{mg}(0.387 \mathrm{mmol}), 32 \%$ yield. FC performed with a mixture of Hexane/Ethyl Acetate as eluant in gradient from 20:1 to 10:1. ${ }^{1} \mathrm{H}$ NMR $\left(300 \mathrm{MHz}, \mathrm{CDCl}_{3}\right) \delta 10.42(\mathrm{~s}, 1 \mathrm{H}), 8.52(\mathrm{~d}, J=8.5 \mathrm{~Hz}$, $1 \mathrm{H}), 7.64-7.57(\mathrm{~m}, 2 \mathrm{H}), 7.13-6.97(\mathrm{~m}, 1 \mathrm{H}), 5.92(\mathrm{ddd}, J=17.0$, $10.5,6.3 \mathrm{~Hz}, 1 \mathrm{H}), 5.63(\mathrm{p}, J=6.5 \mathrm{~Hz}, 1 \mathrm{H}), 5.39(\mathrm{~d}, J=17.2 \mathrm{~Hz}$, $1 \mathrm{H}), 5.26(\mathrm{~d}, J=10.5 \mathrm{~Hz}, 1 \mathrm{H}), 1.52(\mathrm{~s}, 9 \mathrm{H}), 1.47(\mathrm{~d}, J=6.5 \mathrm{~Hz}$,

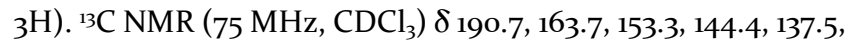
136.9, 134.1, 121.9, 119.8, 118.4, 117.3, 81.8, 74.5, 28.9, 20.6. HRMS (ESI): calcd for $\mathrm{C}_{17} \mathrm{H}_{21} \mathrm{NO}_{5} \mathrm{Na}[\mathrm{M}+\mathrm{Na}]^{+} 342.1317$; found 342.1303 . 3-bromopropyl 2-(2-((Boc)amino)phenyl)-2-oxoacetate (3aj). $182 \mathrm{mg}$ ( $0.472 \mathrm{mmol}), 39 \%$ yield. FC performed with a mixture of Hexane/Ethyl Acetate as eluant in ratio 6o:1. ${ }^{1} \mathrm{H}$ NMR (400 $\left.\mathrm{MHz}, \mathrm{CDCl}_{3}\right) \delta 10.37(\mathrm{~s}, 1 \mathrm{H}), 8.53(\mathrm{~d}, \mathrm{~J}=8.5 \mathrm{~Hz}, 1 \mathrm{H}), 7.7 \mathrm{O}-7.5 \mathrm{O}$ $(\mathrm{m}, 2 \mathrm{H}), 7.13-7.01(\mathrm{~m}, 1 \mathrm{H}), 4.54(\mathrm{t}, \mathrm{J}=6 . \mathrm{o} \mathrm{Hz}, 2 \mathrm{H}), 3.49(\mathrm{t}, \mathrm{J}=$ $6.4 \mathrm{~Hz}, 2 \mathrm{H}), 2.30(\mathrm{q}, \mathrm{J}=6.2 \mathrm{~Hz}, 2 \mathrm{H}), 1.53(\mathrm{~s}, 9 \mathrm{H}) .{ }^{13} \mathrm{C}$ NMR (101 $\left.\mathrm{MHz}, \mathrm{CDCl}_{3}\right) \delta 189.9,163.8$, 152.9, 144.0, 137.3, 133.8, 121.6, 119.5, $116.8,81.5,64.1,31.5,29.1,28.5$. HRMS (ESI): calcd for $\mathrm{C}_{16} \mathrm{H}_{20} \mathrm{NO}_{5} \mathrm{NaBr}[\mathrm{M}+\mathrm{Na}]^{+} 408.0423$; found 408.0437 .

3-bromopropyl 2-(2-((Boc)amino)-5-chlorophenyl)-2-oxoacetate ( $3 \mathrm{bj})$. $120 \mathrm{mg}(0.286 \mathrm{mmol}), 27 \%$ yield. FC performed with a mixture of Hexane/Ethyl Acetate as eluant in gradient from 6o:1 to $40: 1 .{ }^{1} \mathrm{H}$ NMR (40o MHz, $\mathrm{CDCl}_{3}$ ) $\delta 10.27(\mathrm{~s}, 1 \mathrm{H}), 8.51$ (d, $J=9.2 \mathrm{~Hz}, 1 \mathrm{H}), 7.63(\mathrm{~d}, \mathrm{~J}=2.4 \mathrm{~Hz}, 1 \mathrm{H}), 7.53(\mathrm{dd}, \mathrm{J}=9.2,2.4 \mathrm{~Hz}$, $1 \mathrm{H}), 4.55(\mathrm{t}, \mathrm{J}=6 . \mathrm{O} \mathrm{Hz}, 2 \mathrm{H}), 3.5 \mathrm{O}(\mathrm{t}, \mathrm{J}=6.3 \mathrm{~Hz}, 2 \mathrm{H}), 2.31(\mathrm{p}, \mathrm{J}=$ $6.2 \mathrm{~Hz}, 2 \mathrm{H}), 1.51(\mathrm{~s}, 9 \mathrm{H}) .{ }_{13} \mathrm{C}$ NMR $\left(101 \mathrm{MHz}, \mathrm{CDCl}_{3}\right) \delta 188.6$, 163.0, 152.7, 142.5, 137.0, 132.6, 126.6, 121.1, 117.8, 81.9, 64.4, 31.4, 28.9, 28.5. HRMS (ESI): calcd for $\mathrm{C}_{15} \mathrm{H}_{20} \mathrm{ClNO}_{6} \mathrm{Na}$ [M$\left.\mathrm{O}\left(\mathrm{CH}_{2}\right)_{3} \mathrm{Br}+\left(\mathrm{OCH}_{3}\right)_{2}+\mathrm{H}+\mathrm{Na}\right]^{+}{ }_{368.0877}$; found 368.0858 .

But-3-en-2-yl 2-(2-((Boc)amino)-5-chlorophenyl)-2-oxoacetate (3bh). $113 \mathrm{mg}$ ( $0.319 \mathrm{mmol}), 59 \%$ yield. FC performed with a mixture of He xane/Ethyl Acetate as eluant in gradient from 40:1 to 10:1. ${ }^{1} \mathrm{H}$ NMR (300 MHz, $\left.\mathrm{CDCl}_{3}\right) \delta 10.33(\mathrm{~s}, 1 \mathrm{H}), 8.51$ (d, $J$ $=9.2 \mathrm{~Hz}, 1 \mathrm{H}), 7.63(\mathrm{~d}, J=2.4 \mathrm{~Hz}, 1 \mathrm{H}), 7.53(\mathrm{dd}, J=9.2,2.5 \mathrm{~Hz}$, $1 \mathrm{H}), 5.93(\mathrm{ddd}, J=17.0,10.5,6.4 \mathrm{~Hz}, 1 \mathrm{H}), 5.64(\mathrm{p}, J=6.5 \mathrm{~Hz}, 1 \mathrm{H})$, 5.35 (dd, $J=35.8,13.8 \mathrm{~Hz}, 2 \mathrm{H}), 1.52(\mathrm{~s}, 9 \mathrm{H}) .13 \mathrm{C}$ NMR $(75 \mathrm{MHz}$, $\left.\mathrm{CDCl}_{3}\right) \delta 189.0,162.6,152.7,142.5,136.8,136.3,132.7,126.4$, 121.o, $118.3,117.9,81.7,74.4,28.4$, 20.1. HRMS (ESI): calcd for $\mathrm{C}_{15} \mathrm{H}_{20} \mathrm{NO}_{6} \mathrm{NaCl} \quad\left[\mathrm{M}-\mathrm{OCH}\left(\mathrm{CH}_{3}\right) \mathrm{CH}=\mathrm{CH}_{2}+\left(\mathrm{OCH}_{3}\right)_{2}+\mathrm{H}+\mathrm{Na}\right]^{+}$ 368.0877; found 368.0833 .

Synthesis of 2-( $N$-Boc-anilino)- $\alpha$-ketoesters 3 cb-zeb. 200 $\mathrm{mg}$ of 5 -substituted isatin (1.24 mmol, 1 equiv) and $61 \mathrm{mg}$ DMAP (o.497 mmol, $40 \mathrm{~mol} \%$ ) were suspended in $20 \mathrm{~mL}$ of THF at ${ }^{\circ}{ }^{\circ} \mathrm{C}$ (ice bath), then $325 \mathrm{mg}$ of Boc2 $\mathrm{O}(1.49 \mathrm{mmol}, 1.2$ equiv) was added. The reaction was stirred at $0^{\circ} \mathrm{C}$ for $30 \mathrm{~min}$ and then at room temperature until the disappear of the isatin on TLC plate (eluant hexane/ethyl acetate 2:1). After that, 3.6 $\mathrm{mL}$ of EtOH (62.1 mmol, 50 equiv) and $69.1 \mu \mathrm{L}$ of Et3N (o.497 mmol, $40 \mathrm{~mol} \%$ ) were added and the mixture was stirred at room temperature for $30 \mathrm{~min}$. Solvents were evaporated at reduced pressure and the crude was purified with flash silica chromatography using as eluant a mixture of hexane/ethyl acetate (30:1) to afford the products as yellow oils.

Ethyl 2-(2-((Boc)amino)-5-bromophenyl)-2-oxoacetate (3cb). $158 \mathrm{mg}(0.420 \mathrm{mmol}), 45 \%$ yield. FC performed with a mixture of Hexane/Ethyl Acetate as eluant in gradient from 80:1 to 50:1. ${ }^{1} \mathrm{H}$ NMR (300 MHz, $\left.\mathrm{CDCl}_{3}\right) \delta 10.32(\mathrm{~s}, 1 \mathrm{H}), 8.46(\mathrm{~d}, \mathrm{~J}=9.2 \mathrm{~Hz}$, $1 \mathrm{H}), 7.78(\mathrm{~d}, J=2.3 \mathrm{~Hz}, 1 \mathrm{H}), 7.67(\mathrm{dd}, J=9.2,2.3 \mathrm{~Hz}, 1 \mathrm{H}), 4.46$ $(\mathrm{q}, \mathrm{J}=7.2 \mathrm{~Hz}, 2 \mathrm{H}), 1.52(\mathrm{~s}, 9 \mathrm{H}), 1.43\left(\mathrm{t}, \mathrm{J}=7.2 \mathrm{~Hz},{ }_{3} \mathrm{H}\right) .{ }^{13} \mathrm{C}$ NMR
(101 MHz, $\mathrm{CDCl}_{3}$ ) $\delta$ 189.1, 163.3, 152.7, 143.0, 139.7, 135.7, 121.3, 118.4, 113.6, 81.9, 63.1, 28.5, 14.4. HRMS (ESI): calcd for $\mathrm{C}_{15} \mathrm{H}_{20} \mathrm{BrNO}_{6} \mathrm{Na} \quad\left[\mathrm{M}-\mathrm{OCH}_{2} \mathrm{CH}_{3}+\left(\mathrm{OCH}_{3}\right)_{2}+\mathrm{H}+\mathrm{Na}\right]^{+} \quad 412.0372$; found 412.0346 .

Ethyl 2-(2-((Boc)amino)-5-methylphenyl)-2-oxoacetate (3db). $217 \mathrm{mg}$ ( $0.707 \mathrm{mmol}), 57 \%$ yield. FC performed with a mixture of Hexane/Ethyl Acetate as eluant in ratio 10:1. ${ }^{1} \mathrm{H}$ NMR (400 $\left.\mathrm{MHz}, \mathrm{CDCl}_{3}\right) \delta 10.29(\mathrm{~s}, 1 \mathrm{H}), 8.4 \mathrm{O}\left(\mathrm{d}, \mathrm{J}=8.9 \mathrm{~Hz},{ }_{1 \mathrm{H}}\right), 7.42-7.4 \mathrm{O}$ $(\mathrm{m}, 2 \mathrm{H}), 4.46(\mathrm{q}, \mathrm{J}=7.1 \mathrm{~Hz}, 2 \mathrm{H}), 2.32(\mathrm{~s}, 3 \mathrm{H}), 1.52(\mathrm{~s}, 9 \mathrm{H}), 1.42$ $\left(\mathrm{t}, \mathrm{J}=7.1 \mathrm{~Hz},{ }_{3} \mathrm{H}\right) .{ }^{13} \mathrm{C}$ NMR $\left(101 \mathrm{MHz}, \mathrm{CDCl}_{3}\right) \delta 190.4,164.2$, 153.1, 141.7, 138.1, 133.6, 131.0, 119.5, 116.9, 81.3, 62.7, 28.6, 20.8, 14.4. HRMS (ESI): calcd for $\mathrm{C}_{16} \mathrm{H}_{21} \mathrm{NO}_{5} \mathrm{Na}[\mathrm{M}+\mathrm{Na}]^{+} 330.1317$; found 330.1329 .

Ethyl 2-(2-((Boc)amino)-5-nitrophenyl)-2-oxoacetate (3eb). 169 $\mathrm{mg}(0.499 \mathrm{mmol}), 48 \%$ yield. FC performed with a mixture of Hexane/Ethyl Acetate as eluant in ratio 10:1. ${ }^{1} \mathrm{H}$ NMR (300 $\left.\mathrm{MHz}, \mathrm{CDCl}_{3}\right) \delta 10.71(\mathrm{~s}, 1 \mathrm{H}), 8.75(\mathrm{~d}, \mathrm{~J}=9.5 \mathrm{~Hz}, 1 \mathrm{H}), 8.67(\mathrm{~d}, \mathrm{~J}=$ $2.6 \mathrm{~Hz}, 1 \mathrm{H}), 8.42(\mathrm{dd}, \mathrm{J}=9.5,2.6 \mathrm{~Hz}, 1 \mathrm{H}), 4.52(\mathrm{q}, \mathrm{J}=7.1 \mathrm{~Hz}$, $2 \mathrm{H}), 1.55(\mathrm{~s}, 9 \mathrm{H}), 1.46\left(\mathrm{t}, \mathrm{J}=7.1 \mathrm{~Hz},{ }_{3} \mathrm{H}\right) .{ }^{13} \mathrm{C}$ NMR $(75 \mathrm{MHz}$, $\left.\mathrm{CDCl}_{3}\right) \delta$ 188.9, 162.7, 152.2, 148.9, 141.0, 131.3, 129.7, 119.7, 116.1, 83.1, 63.6, 28.4, 14.4. HRMS (ESI): calcd for $\mathrm{C}_{15} \mathrm{H}_{20} \mathrm{~N}_{2} \mathrm{O}_{8} \mathrm{Na}$ [M$\left.\mathrm{OCH}_{2} \mathrm{CH}_{3}+\left(\mathrm{OCH}_{3}\right)_{2}+\mathrm{H}+\mathrm{Na}\right]^{+}$379.1117; found 379.1096.

Synthesis of 2-( $N$-Boc-anilino)- $\alpha$-ketoamides zai-zam. To a stirred solution of the $\mathrm{N}$-Boc isatin (300 $\mathrm{mg}, 1.21 \mathrm{mmol}$, 1 equiv) in $10 \mathrm{~mL}$ dichloromethane was added a mixture of the amino acid (372/639 mg, $2.96 \mathrm{mmol}, 2.45$ equiv) and saturated sodium hydrogen carbonate solution $(3 \mathrm{~mL})$ in $7 \mathrm{~mL}$ water at $5^{\circ} \mathrm{C}$. The reaction mixture was warmed to room temperature and stirred for $24 \mathrm{~h}$. The organic layer was diluted with $20 \mathrm{~mL}$ of dichloromethane and extracted with $15 \mathrm{~mL}$ of aqueous hydrochloric acid $0.5 \mathrm{M}$ and $20 \mathrm{~mL}$ water. The organic extract was dried over anhydrous $\mathrm{Na}_{2} \mathrm{SO}_{4}$, filtered and concentrated under vacuum. The crude product was purified by gravity column chromatography over silica with dichloromethane to give the product as a yellow oil.

Boc (2-(2-(butylamino)-2-oxoacetyl)phenyl)carbamate (3ai). $310 \mathrm{mg}$ ( $0.968 \mathrm{mmol}), 80 \%$ yield. FC performed with Dichloromethane as eluant. ${ }^{1} \mathrm{H}$ NMR $\left(300 \mathrm{MHz}, \mathrm{CDCl}_{3}\right) \delta 10.27$ $(\mathrm{s}, 1 \mathrm{H}), 8.40(\mathrm{~d}, J=8.6 \mathrm{~Hz}, 1 \mathrm{H}), 8.33(\mathrm{~d}, J=8.1 \mathrm{~Hz}, 1 \mathrm{H}), 7.53(\mathrm{t}$, $J=7.9 \mathrm{~Hz}, 1 \mathrm{H}), 7.01(\mathrm{t}, J=7.7 \mathrm{~Hz}, 1 \mathrm{H}), 3.37(\mathrm{dd}, J=13.3,6.8 \mathrm{~Hz}$, $2 \mathrm{H}), 1.58(\mathrm{~m}, 2 \mathrm{H}), 1.51(\mathrm{~s}, 9 \mathrm{H}), 1.38(\mathrm{~m}, 2 \mathrm{H}), 0.93(\mathrm{t}, J=7.3 \mathrm{~Hz}$, $\left.{ }_{3} \mathrm{H}\right) .{ }^{13 \mathrm{C}} \mathrm{NMR}\left(75 \mathrm{MHz}, \mathrm{CDCl}_{3}\right) \delta 192.4,163.7,153.4,143.9,137.0$, 135.1, 121.8, 119.7, 118.8, 81.6, 40.0, 32.0, 28.9, 20.7, 14.4. HRMS (ESI): calcd for $\mathrm{C}_{17} \mathrm{H}_{24} \mathrm{~N}_{2} \mathrm{O}_{4} \mathrm{Na}[\mathrm{M}+\mathrm{Na}]^{+} 343.1634$; found 343.1652.

Methyl (2-(2-((Boc)amino)phenyl)-2-oxoacetyl)glycinate (3ak). $310 \mathrm{mg}$ (0.921 mmol), $76 \%$ yield. ${ }^{1} \mathrm{H}$ NMR (400 MHz, $\left.\mathrm{CDCl}_{3}\right) \delta 10.20(\mathrm{~s}, 1 \mathrm{H}), 8.31(\mathrm{~d}, \mathrm{~J}=8.6 \mathrm{~Hz}, \mathrm{H}), 8.12(\mathrm{~d}, \mathrm{~J}=8.1 \mathrm{~Hz}$, $1 \mathrm{H}), 7.66(\mathrm{t}, J=5.6 \mathrm{~Hz}, 1 \mathrm{H}), 7.45(\mathrm{t}, J=8.0 \mathrm{~Hz}, 1 \mathrm{H}), 6.92(\mathrm{t}, J=$ $7.7 \mathrm{~Hz}, 1 \mathrm{H}), 4.05(\mathrm{~d}, \mathrm{~J}=5.7 \mathrm{~Hz}, 2 \mathrm{H}), 3.66(\mathrm{~s}, 3 \mathrm{H}), 1.44(\mathrm{~s}, 9 \mathrm{H})$. ${ }_{13} \mathrm{C}$ NMR (101 $\mathrm{MHz}, \mathrm{CDCl}_{3}$ ) $\delta 191.2,169.6,163.9,152.7,143.2$, 136.5, 134.4, 121.3, 119.0, 117.8, 81.1, 52.5, 41.1, 28.3. HRMS (ESI): calcd for $\mathrm{C}_{16} \mathrm{H}_{20} \mathrm{~N}_{2} \mathrm{O}_{6} \mathrm{~K}[\mathrm{M}+\mathrm{K}]^{+} 375.0958$; found 375.0979 .

Methyl (2-(2-((Boc)amino)phenyl)-2-oxoacetyl)-L-phenylalalinate (3al). $445 \mathrm{mg}(1.05 \mathrm{mmol}), 86 \%$ yield. ${ }^{1} \mathrm{H}$ NMR ( $400 \mathrm{MHz}$, $\left.\mathrm{CDCl}_{3}\right) \delta 10.28(\mathrm{~s}, 1 \mathrm{H}), 8.41(\mathrm{~d}, \mathrm{~J}=8.6 \mathrm{~Hz}, 1 \mathrm{H}), 8.03(\mathrm{~d}, \mathrm{~J}=8.1$ $\mathrm{Hz}, 1 \mathrm{H}), 7.51(\mathrm{t}, \mathrm{J}=7.9 \mathrm{~Hz}, 1 \mathrm{H}), 7.38-7.23(\mathrm{~m}, 4 \mathrm{H}), 7.16(\mathrm{~d}, \mathrm{~J}=$ $6.9 \mathrm{~Hz}, 2 \mathrm{H}), 6.94(\mathrm{t}, \mathrm{J}=7.7 \mathrm{~Hz}, 1 \mathrm{H}), 5.05-4.88(\mathrm{~m}, 1 \mathrm{H}), 3.73(\mathrm{~s}$, $3 \mathrm{H}), 3.25(\mathrm{dd}, \mathrm{J}=14.0,5.4 \mathrm{~Hz}, 1 \mathrm{H}), 3.11(\mathrm{dd}, \mathrm{J}=13.9,7.1 \mathrm{~Hz}, 1 \mathrm{H})$, 1.52 (s, $9 \mathrm{H}) .{ }^{3} \mathrm{C}$ NMR (101 MHz, $\left.\mathrm{CDCl}_{3}\right) \delta 191.2,171.4,163.2,153.0$, 143.6, 136.8, 135.8, 134.7, 129.6, 129.1, 127.6, 121.4, 119.3, 118.o, 81.3, 
53.6, 52.9, 38.2, 28.6. HRMS (ESI): calcd for $\mathrm{C}_{23} \mathrm{H}_{26} \mathrm{~N}_{2} \mathrm{O}_{6} \mathrm{Na}$ $[\mathrm{M}+\mathrm{Na}]^{+}$449.1689; found 449.1699.

Methyl (2-(2-((Boc)amino)phenyl)-2-oxoacetyl)-L-valinate (3am). $310 \mathrm{mg}$ (o.820 mmol), $68 \%$ yield. ${ }^{1} \mathrm{H}$ NMR (400 MHz, $\left.\mathrm{CDCl}_{3}\right) \delta 10.65(\mathrm{~s}, 1 \mathrm{H}), 8.72(\mathrm{~d}, J=8.6 \mathrm{~Hz}, 1 \mathrm{H}), 8.54(\mathrm{~d}, J=8.1$ $\left.\mathrm{Hz},{ }_{1} \mathrm{H}\right), 7.84(\mathrm{t}, J=7.9 \mathrm{~Hz}, 1 \mathrm{H}), 7.74\left(\mathrm{~d}, J=8.9 \mathrm{~Hz},{ }_{1} \mathrm{H}\right), 7.29(\mathrm{t}$, $J=7.6 \mathrm{~Hz}, 1 \mathrm{H}), 4.93(\mathrm{dd}, J=8.9,4.9 \mathrm{~Hz}, 1 \mathrm{H}), 4.08(\mathrm{~s}, 3 \mathrm{H}), 2.78$ - $2.35(\mathrm{~m}, 1 \mathrm{H}), 1.84(\mathrm{~s}, 9 \mathrm{H}), 1.30(\mathrm{dd}, J=16.6,6.8 \mathrm{~Hz}, 6 \mathrm{H}) .{ }^{13} \mathrm{C}$ NMR (101 MHz, $\mathrm{CDCl}_{3}$ ) $\delta 190.8,171.3,163.0,152.5,143.1,136.3$, 134.2, 121.0, 118.8, 117.6, 80.8, 57.2, 52.2, 31.2, 28.1, 18.9, 17.6. HRMS (ESI): calcd for $\mathrm{C}_{19} \mathrm{H}_{26} \mathrm{~N}_{2} \mathrm{O}_{6} \mathrm{Na}[\mathrm{M}+\mathrm{Na}]^{+} 401.1689$; found 401.1674.

Synthesis of benzoazetidines 4 aa-5db. $100 \mathrm{mg}$ of 3 (o.34 mmol, 1 equiv) were dissolved in $1.2 \mathrm{~mL}$ of dichloromethane. The solution was cooled down to $4{ }^{\circ} \mathrm{C}$. After 10 minutes 230 $\mathrm{mg}$ of $\mathrm{Boc}_{2} \mathrm{O}$ (1.06 mmol, 3.1 equiv) were added and the solution was stirred for 30 minutes at the same temperature. After that time $6 \mathrm{mg}$ of DMAP (0.051 mmol, $15 \mathrm{~mol} \%$ ) were added and the mixture was stirred for 1-48 h. The crude was purified with flash silica chromatography using as eluant a mixture of hexane/ethyl acetate (30:1 to 5:1).

7-(tert-butyl) 8-methyl 8-((tert-butoxycarbonyl)oxy)-7-azabicicyclo[4.2.o]octa-1,3,5-triene-7,8-dicarboxylate (4aa). Performed on $84 \mathrm{mg}$ of 3aa. $52 \mathrm{mg}$ ( $0.137 \mathrm{mmol}), 46 \%$ yield. FC performed with a mixture of Petroleum Ether/Ethyl Acetate as eluant in gradient from 20:1 to 5:1. ${ }^{1} \mathrm{H} \mathrm{NMR}\left(400 \mathrm{MHz}, \mathrm{CDCl}_{3}\right)$ $\delta 7.88\left(\mathrm{~d}, \mathrm{~J}=8.1 \mathrm{~Hz},{ }_{1} \mathrm{H}\right), 7.42(\mathrm{ddd}, \mathrm{J}=9.4,5.8,1.9 \mathrm{~Hz}, 2 \mathrm{H}), 7.19$ (td, J = 7.6, 0.9 Hz, $1 \mathrm{H}), 3.69\left(\mathrm{~s},{ }_{3} \mathrm{H}\right), 1.64(\mathrm{~s}, 9 \mathrm{H}), 1.34(\mathrm{~s}, 9 \mathrm{H})$. ${ }_{13} \mathrm{C}$ NMR (101 $\left.\mathrm{MHz}, \mathrm{CDCl}_{3}\right) \delta 167.1,149.9,148.8,140.0,131.4$, 124.7, 124.2, 123.2, 115.6, 96.3, 84.7, 84.1, 52.4, 28.1, 27.4. HRMS (ESI): calcd for $\mathrm{C}_{19} \mathrm{H}_{25} \mathrm{NO}_{7} \mathrm{Na}[\mathrm{M}+\mathrm{Na}]^{+}$402.1529; found 402.1528 .

7-(tert-butyl) 8-ethyl 8-((tert-butoxycarbonyl)oxy)-7-azabicicyclo[4.2.0]octa-1,3,5-triene-7,8-dicarboxylate (4ab). Performed on $77 \mathrm{mg}$ of 3 ab. $63 \mathrm{mg}$ (0.16o mmol), $61 \%$ yield. FC performed with a mixture of Hexane/Ethyl Acetate as eluant in gradient from 40:1 to 5:1. ${ }^{1} \mathrm{H}$ NMR $\left(400 \mathrm{MHz} \mathrm{CDCl}_{3}\right) \delta 7.88$ $(\mathrm{d}, \mathrm{J}=8.2 \mathrm{~Hz}, 1 \mathrm{H}), 7.46-7.36(\mathrm{~m}, 2 \mathrm{H}), 7.19(\mathrm{td}, \mathrm{J}=7.6,0.9 \mathrm{~Hz}$, $1 \mathrm{H}), 4.14-4.00(\mathrm{~m}, 2 \mathrm{H}), 1.64(\mathrm{~s}, 9 \mathrm{H}), 1.33(\mathrm{~s}, 9 \mathrm{H}), 1.21(\mathrm{t}, \mathrm{J}=7.1$ $\left.\mathrm{Hz},{ }_{3} \mathrm{H}\right) .{ }^{13 \mathrm{C}} \mathrm{NMR}\left(101 \mathrm{MHz}, \mathrm{CDCl}_{3}\right) \delta 167.8,150.3,149.2,140.3$, 131.6, 125.0, 124.9, 123.6, 115.9, 96.8, 85.0, 84.4, 61.0, 28.4, 27.8, 15.5. HRMS (ESI): calcd for $\mathrm{C}_{20} \mathrm{H}_{27} \mathrm{NO}_{7} \mathrm{Na}[\mathrm{M}+\mathrm{Na}]^{+}{ }_{416.1685}$; found 416.1666 .

7-(tert-butyl) 8-(2-oxopropyl) 8-((tert-butoxycarbonyl)oxy)-7azabicicyclo[4.2.0]octa-1,3,5-triene-7,8-dicarboxylate (4ac). Performed on $100 \mathrm{mg}$ of 3ac. $71 \mathrm{mg}$ (0.168 mmol), $54 \%$ yield. FC performed with a mixture of Hexane/Diethyl Ether as eluant in gradient from 20:1 to 1:1. ${ }^{1} \mathrm{H} \mathrm{NMR}\left(400 \mathrm{MHz}, \mathrm{CDCl}_{3}\right) \delta$ $7.88(\mathrm{~d}, \mathrm{~J}=8.2 \mathrm{~Hz}, 1 \mathrm{H}), 7.5 \mathrm{O}-7.40(\mathrm{~m}, 2 \mathrm{H}), 7.21(\mathrm{td}, \mathrm{J}=7.6,0.8$ $\mathrm{Hz}, 1 \mathrm{H}), 4.74(\mathrm{~d}, \mathrm{~J}=17.1 \mathrm{~Hz}, \mathrm{lH}), 4.59(\mathrm{~d}, \mathrm{~J}=17.1 \mathrm{~Hz}, 1 \mathrm{H}), 2.16$ $(\mathrm{s}, 3 \mathrm{H}), 1.63(\mathrm{~s}, 9 \mathrm{H}), 1.34(\mathrm{~s}, 9 \mathrm{H}) .{ }^{13} \mathrm{C}$ NMR $\left(101 \mathrm{MHz}, \mathrm{CDCl}_{3}\right) \delta$ 204.6, 167.9, 150.0, 149.1, 140.6, 132.2, 125.5, 124.3, 123.8, 116.1, 96.0, 85.4, 85.1, 69.7, 28.5, 27.9, 26.9. HRMS (ESI): calcd for $\mathrm{C}_{21} \mathrm{H}_{27} \mathrm{NO}_{8} \mathrm{Na}[\mathrm{M}+\mathrm{Na}]^{+} 444.1634$; found 444.1625.

7-(tert-butyl) 8-(2-ethoxy-2-oxoethyl) 8-((tert-butoxycarbonyl)oxy)-7-azabicicyclo[4.2.o]octa-1,3,5-triene-7,8-dicarboxylate (4ad). Performed on $59 \mathrm{mg}$ of zad. $29 \mathrm{mg}$ (0.0643 mmol), $38 \%$ yield. FC performed with a mixture of Petroleum Ether/Ethyl Acetate as eluant in gradient from 20:1 to 1:1. ${ }^{1} \mathrm{H}$ NMR (40o MHz, $\left.\mathrm{CDCl}_{3}\right) \delta 7.88\left(\mathrm{~d}, \mathrm{~J}=8.2 \mathrm{~Hz},{ }_{1} \mathrm{H}\right), 7.52-7.46$ $(\mathrm{m}, \mathrm{1H}), 7.45-7.39(\mathrm{~m}, \mathrm{H}), 7.22-7.18(\mathrm{~m}, \mathrm{lH}), 4.82(\mathrm{~d}, \mathrm{~J}=16.3$
$\mathrm{Hz}, 1 \mathrm{H}), 4.55(\mathrm{~d}, \mathrm{~J}=16.3 \mathrm{~Hz}, 1 \mathrm{H}), 4.18(\mathrm{q}, \mathrm{J}=7.1 \mathrm{~Hz}, 2 \mathrm{H}), 1.63(\mathrm{~s}$, $9 \mathrm{H}), 1.34(\mathrm{~s}, 9 \mathrm{H}), 1.24\left(\mathrm{~d}, \mathrm{~J}=7.2 \mathrm{~Hz},{ }_{3} \mathrm{H}\right) .{ }^{13} \mathrm{C}$ NMR (101 MHz, $\left.\mathrm{CDCl}_{3}\right) \delta$ 169.1, 167.6, 149.9, 149.0, 140.5, 132.0, 125.3, 124.2, 123.7, $115.9,95.8,85.0,84.8,62.2,61.4,28.4,27.8,14.4$. HRMS (ESI): calcd for $\mathrm{C}_{22} \mathrm{H}_{29} \mathrm{NO}_{9} \mathrm{Na}[\mathrm{M}+\mathrm{Na}]^{+} 474.1740$; found 474.1719.

7-(tert-butyl) 8-(2-chloroethyl) 8-((tert-butoxycarbonyl)oxy)7-azabicicyclo[4.2.o]octa-1,3,5-triene-7,8-dicarboxylate (4ae). Performed on $100 \mathrm{mg}$ of 3ae. $61 \mathrm{mg}$ (0.143 mmol), $47 \%$ yield. FC performed with a mixture of Petroleum Ether/Diethyl Ether as eluant in gradient from 30:1 to 25:1. ${ }^{1} \mathrm{H}$ NMR (400 $\left.\mathrm{MHz}^{\mathrm{CDCl}}{ }_{3}\right) \delta 7.88(\mathrm{~d}, \mathrm{~J}=8.2 \mathrm{~Hz}, 1 \mathrm{H}), 7.46-7.40(\mathrm{~m}, 2 \mathrm{H}), 7.20$ $(\mathrm{td}, \mathrm{J}=7.6,0.9 \mathrm{~Hz}, 1 \mathrm{H}), 4.31(\mathrm{td}, \mathrm{J}=6.1,1.5 \mathrm{~Hz}, 2 \mathrm{H}), 3.63(\mathrm{td}, \mathrm{J}$ $=6.2,0.8 \mathrm{~Hz}, 2 \mathrm{H}), 1.64(\mathrm{~s}, 9 \mathrm{H}), 1.34(\mathrm{~s}, 9 \mathrm{H}) .{ }^{13} \mathrm{C}$ NMR $(101 \mathrm{MHz}$, $\left.\mathrm{CDCl}_{3}\right) \delta 167.3,149.6,148.7,140.0,131.6,124.9,124.1,123.3,115.6$, 96.o, 84.8, 84.4, 64.5, 42.3, 28.1, 27.4. HRMS (ESI): calcd for $\mathrm{C}_{20} \mathrm{H}_{26} \mathrm{NO}_{7} \mathrm{NaCl}[\mathrm{M}+\mathrm{Na}]^{+}$450.1295; found 450.1286 .

7-(tert-butyl) 8-(2-iodoethyl) 8-((tert-butoxycarbonyl)oxy)-7azabicicyclo[4.2.0]octa-1,3,5-triene-7,8-dicarboxylate (4af). Performed on $18 \mathrm{mg}$ of zaf. $5 \mathrm{mg}$ (0.00945 mmol), $22 \%$ yield. FC performed with a mixture of Hexane/Diethyl Ether as eluant in gradient from 20:1 to 10:1. ${ }^{1 \mathrm{H} N M R}\left(400 \mathrm{MHz}, \mathrm{CDCl}_{3}\right) \delta$ $7.88(\mathrm{~d}, \mathrm{~J}=8.1 \mathrm{~Hz}, 1 \mathrm{H}), 7.50-7.38(\mathrm{~m}, 2 \mathrm{H}), 7.21(\mathrm{t}, \mathrm{J}=7.1 \mathrm{~Hz}$, $1 \mathrm{H}), 4.30(\mathrm{td}, \mathrm{J}=7.1,1.2 \mathrm{~Hz}, 2 \mathrm{H}), 3.24(\mathrm{t}, \mathrm{J}=7.2 \mathrm{~Hz}, 2 \mathrm{H}), 1.64(\mathrm{~s}$, $9 \mathrm{H}), 1.34$ (s, 9H). ${ }^{13 C}$ NMR (101 MHz, $\left.\mathrm{CDCl}_{3}\right) \delta 167.7,150.0,149.1$, 140.3, 131.9, 125.2, 125.1, 123.6, 115.9, 96.2, 85.2, 84.8, 65.5, 28.4, 27.8, 1.8. HRMS (ESI): calcd for $\mathrm{C}_{20} \mathrm{H}_{26} \mathrm{NO}_{7} \mathrm{KI}[\mathrm{M}+\mathrm{K}]^{+} 558.0391$; found 558.0364 .

8-allyl 7-(tert-butyl) 8-((tert-butoxycarbonyl)oxy)-7-azabicicyclo[4.2.o]octa-1,3,5-triene-7,8-dicarboxylate (4ag). Performed on $100 \mathrm{mg}$ of $3 \mathrm{ag} .47 \mathrm{mg}$ (0.112 mmol), $36 \%$ yield. FC performed with a mixture of Petroleum Ether/Ethyl Acetate as eluant in gradient from 20:1 to 8:1. ${ }^{1} \mathrm{H} \mathrm{NMR}\left(400 \mathrm{MHz}, \mathrm{CDCl}_{3}\right) \delta$ $7.87(\mathrm{~d}, \mathrm{~J}=8.2 \mathrm{~Hz}, 1 \mathrm{H}), 7.45(\mathrm{~d}, \mathrm{~J}=7.4 \mathrm{~Hz}, \mathrm{iH}), 7.41(\mathrm{dd}, \mathrm{J}=11.3$, $4.5 \mathrm{~Hz}, 1 \mathrm{H}), 5.90(\mathrm{ddt}, \mathrm{J}=\mathbf{2 2 . 8}, 10.9,5.7 \mathrm{~Hz}, 1 \mathrm{H}), 5.28(\mathrm{dd}, \mathrm{J}=$ 17.2, 1.2 Hz, $1 \mathrm{H}), 5.16(\mathrm{~d}, \mathrm{~J}=10.4 \mathrm{~Hz}, 1 \mathrm{H}), 4.71-4.46(\mathrm{~m}, 2 \mathrm{H})$, $1.64(\mathrm{~s}, 9 \mathrm{H}), 1.34(\mathrm{~s}, 9 \mathrm{H}) .{ }^{13} \mathrm{C}$ NMR $\left(101 \mathrm{MHz} \mathrm{CDCl}_{3}\right) \delta 167.7$, 150.2, 149.2, 140.3, 133.6, 131.7, 125.1, 124.8, 123.6, 118.1, 115.9, 96.5, 85.o, 84.5, 66.1, 28.4, 27.8. HRMS (ESI): calcd for $\mathrm{C}_{21} \mathrm{H}_{27} \mathrm{NO}_{7} \mathrm{Na}$ $[\mathrm{M}+\mathrm{Na}]^{+} 428.1685$; found 428.1665 .

8-(but-3-en-2-yl) 7-(tert-butyl) 8-((tert-butoxycarbonyl)oxy)-7azabicicyclo[4.2.o]octa-1,3,5-triene-7,8-dicarboxylate (4ah). Performed on $64 \mathrm{mg}$ of zah. $46 \mathrm{mg}$ (o.110 mmol), $54 \%$ yield. FC performed with a mixture of Petroleum Ether/Ethyl Acetate as eluant in gradient from 20:1 to 7:1. ${ }^{1} \mathrm{H}$ NMR (400 MHz, $\left.\mathrm{CDCl}_{3}\right) \delta_{7.87}(\mathrm{dd}, \mathrm{J}=8.1,2.7 \mathrm{~Hz}, 1 \mathrm{H}), 7.49-7.35(\mathrm{~m}, 2 \mathrm{H}), 7.18$ $(\mathrm{td}, \mathrm{J}=7.6,0.9 \mathrm{~Hz}, 1 \mathrm{H}), 5.94-5.76(\mathrm{~m}, 1 \mathrm{H}), 5.24-4.95\left(\mathrm{~m},{ }_{3} \mathrm{H}\right)$, $1.64(\mathrm{~s}, 9 \mathrm{H}), 1.33(\mathrm{~s}, 9 \mathrm{H}), 1.26(\mathrm{~d}, \mathrm{~J}=6.4 \mathrm{~Hz}, 3 \mathrm{H}) .{ }^{13} \mathrm{C}$ NMR (101 $\left.\mathrm{MHz} \mathrm{CDCl}_{3}\right) \delta 168.5,150.3,149.2,140.3,139.6,131.6,125.1,123.7$, $123.3,115.8,114.9,96.6,84.9,84.2,72.5,28.4,27.8,21.7$. HRMS (ESI): calcd for $\mathrm{C}_{22} \mathrm{H}_{29} \mathrm{NO}_{7} \mathrm{Na}[\mathrm{M}+\mathrm{Na}]^{+} 442.1842$; found 442.1824 .

Tert-butyl 8-((tert-butoxycarbonyl)(butyl)carbamoyl)-8-((tertbutoxycarbonyl)oxy)-7-azabicicyclo[4.2.o]octa-1,3,5-triene7,8-dicarboxylate (4ai). Performed on $118 \mathrm{mg}$ of zai. $53 \mathrm{mg}$ (o.124 mmol), $34 \%$ yield. FC performed with a mixture of Hexane/Ethyl Acetate as eluant in gradient from 40:1 to $15: 1 .{ }^{1} \mathrm{H}$ NMR (400 MHz, $\left.\mathrm{CDCl}_{3}\right) \delta 8.02(\mathrm{~d}, \mathrm{~J}=8.2 \mathrm{~Hz}, \mathrm{H}), 7.68(\mathrm{~d}, \mathrm{~J}=$ $7.4 \mathrm{~Hz}, 1 \mathrm{H}), 7.55\left(\mathrm{~m},{ }_{1 \mathrm{H}}\right), 7.12(\mathrm{t}, \mathrm{J}=7.5 \mathrm{~Hz}, 1 \mathrm{H}), 3.68-3.62(\mathrm{~m}$, $2 \mathrm{H}), 1.69(\mathrm{~m}, 2 \mathrm{H}), 1.59(\mathrm{~s}, 9 \mathrm{H}), 1.45-1.35(\mathrm{~m}, 2 \mathrm{H}), 1.32(\mathrm{~s}, 9 \mathrm{H})$, $1.09(\mathrm{~s}, 9 \mathrm{H}), 0.97\left(\mathrm{t}, \mathrm{J}=7 \cdot 3 \mathrm{~Hz},{ }_{3} \mathrm{H}\right) .{ }^{13} \mathrm{C}$ NMR $\left(101 \mathrm{MHz}, \mathrm{CDCl}_{3}\right)$ $\delta 151.4,150.5,148.7,136.4,123.4,123.4,123.2,116.0,93.1,84.4$, $83.4,82.3,77.5,45.9,32.3,28.7,28.0,27.7,20.3,14.2$. HRMS 
(ESI): calcd for $\mathrm{C}_{27} \mathrm{H}_{40} \mathrm{~N}_{2} \mathrm{O}_{8} \mathrm{Na}[\mathrm{M}+\mathrm{Na}]^{+}$543.2682; found 543.2689.

8-(3-bromopropyl) 7-(tert-butyl) 8-((tert-butoxycarbonyl)oxy)7-azabicicyclo[4-2.0]octa-1,3,5-triene-7,8-dicarboxylate (4aj). Performed on $60 \mathrm{mg}$ of 3 aj. $31 \mathrm{mg}$ (0.0638 mmol), 41 \% yield. FC performed with a mixture of Petroleum Ether/Ethyl Acetate as eluant in gradient from 20:1 to 10:1. ${ }^{1} \mathrm{H}$ NMR (400 MHz, $\left.\mathrm{CDCl}_{3}\right) \delta 7.89(\mathrm{~d}, \mathrm{~J}=8.1 \mathrm{~Hz}, 1 \mathrm{H}), 7.44-7.43(\mathrm{~m}, 2 \mathrm{H}), 7.20(\mathrm{t}, \mathrm{J}=$ $7.5 \mathrm{~Hz}, 1 \mathrm{H}), 4.13(\mathrm{td}, \mathrm{J}=5.9,1.3 \mathrm{~Hz}, 2 \mathrm{H}), 3.44(\mathrm{t}, \mathrm{J}=6.8 \mathrm{~Hz}, 2 \mathrm{H})$, $2.18-2.10(\mathrm{~m}, 2 \mathrm{H}), 1.63(\mathrm{~d}, \mathrm{~J}=6.4 \mathrm{~Hz}, 9 \mathrm{H}), 1.34(\mathrm{~s}, 9 \mathrm{H}),{ }^{13} \mathrm{C}$ NMR (101 MHz, $\mathrm{CDCl}_{3}$ ) $\delta 167.7,150.1,149.1,140.3,131.8,125.1$, 124.6, 123.6, 115.9, 96.6, 85.1, 84.5, 62.9, 33.2, 30.0, 28.4, 27.8. HRMS (ESI): calcd for $\mathrm{C}_{21} \mathrm{H}_{28} \mathrm{NO}_{7} \mathrm{NaBr}[\mathrm{M}+\mathrm{Na}]^{+}$508.0947; found 508.0934 .

7-(tert-butyl) 8-methyl 8-((tert-butoxycarbonyl)oxy)-3-chloro7-azabicicyclo[4-2.o]octa-1,3,5-triene-7,8-dicarboxylate (4ba). Performed on $156 \mathrm{mg}$ of 3 ba. $97 \mathrm{mg}$ (0.255 mmol), $48 \%$ yield. FC performed with a mixture of Hexane/Ethyl Acetate as eluant in ratio 20:1. ${ }^{1} \mathrm{H}$ NMR $\left(400 \mathrm{MHz}, \mathrm{CDCl}_{3}\right) \delta 7.88-7.80(\mathrm{~m}$, $1 \mathrm{H}), 7.47-7.30(\mathrm{~m}, 2 \mathrm{H}), 3.69(\mathrm{~s}, 3 \mathrm{H}), 1.63(\mathrm{~s}, 9 \mathrm{H}), 1.37(\mathrm{~s}, 9 \mathrm{H})$. ${ }_{13} \mathrm{C}$ NMR (101 $\mathrm{MHz}, \mathrm{CDCl}_{3}$ ) $\delta 166.8,150.3,149.0,138.8,131.6$, 130.6, 126.3, 123.8, 117.3, 96.1, 85.4, 84.8, 52.8, 28.4, 27.8. HRMS (ESI): calcd for $\mathrm{C}_{19} \mathrm{H}_{24} \mathrm{NO}_{7} \mathrm{NaCl}[\mathrm{M}+\mathrm{Na}]^{+} 436.1139$; found 436.1122 .

7-(tert-butyl) 8-ethyl 8-((tert-butoxycarbonyl)oxy)-3-chloro-7azabicicyclo[4.2.0]octa-1,3,5-triene-7,8-dicarboxylate (4bb). Performed on $108 \mathrm{mg}$ of $3 \mathrm{bb} .114 \mathrm{mg}$ ( $0.267 \mathrm{mmol}), 81 \%$ yield. FC performed with a mixture of Petroleum Ether/Ethyl Acetate as eluant in gradient from 6o:1 to $20: 1 .{ }^{1} \mathrm{H}$ NMR $(300 \mathrm{MHz}$, $\left.\mathrm{CDCl}_{3}\right) \delta 7.84(\mathrm{~d}, J=8.7 \mathrm{~Hz}, 1 \mathrm{H}), 7.48-7.30(\mathrm{~m}, 2 \mathrm{H}), 4.16-3.96$ $(\mathrm{m}, 2 \mathrm{H}), 1.63(\mathrm{~s}, 9 \mathrm{H}), 1.36(\mathrm{~s}, 9 \mathrm{H}), 1.22\left(\mathrm{t}, J=7.0 \mathrm{~Hz},{ }_{3} \mathrm{H}\right),{ }^{13} \mathrm{C}$ NMR (75 MHz, $\left.\mathrm{CDCl}_{3}\right) \delta$ 167.1, 150.3, 149.0, 138.7, 131.5, 130.6, 126.7, 123.8, 117.3, 96.2, 85.3, 84.7, 61.2, 28.4, 27.8, 15.4. HRMS (ESI): calcd for $\mathrm{C}_{20} \mathrm{H}_{26} \mathrm{NO}_{7} \mathrm{NaCl}[\mathrm{M}+\mathrm{Na}]^{+}$450.1295; found 450.1289 .

8-(3-bromopropyl) 7-(tert-butyl) 8-((tert-butoxycarbonyl)oxy)3-chloro-7-azabicicyclo[4.2.o]octa-1,3,5-triene-7,8-dicarbox-

ylate (4bj). Performed on $77 \mathrm{mg}$ of $3 \mathrm{bj} .63 \mathrm{mg}$ (0.121 mmol), 66 $\%$ yield. FC performed with a mixture of Petroleum Ether/Ethyl Acetate as eluant in gradient from 6o:1 to 20:1. ${ }^{1} \mathrm{H}$ NMR (400 MHz, $\left.\mathrm{CDCl}_{3}\right) \delta 7.85(\mathrm{~d}, J=8.6 \mathrm{~Hz}, 1 \mathrm{H}), 7.41-7.37(\mathrm{~m}$, $2 \mathrm{H}), 4.14(\mathrm{t}, J=6 . \mathrm{o} \mathrm{Hz}, 2 \mathrm{H}), 3.45(\mathrm{t}, J=6.7 \mathrm{~Hz}, 2 \mathrm{H}), 2.14(\mathrm{p}, J=$ $6.3 \mathrm{~Hz}, 2 \mathrm{H}), 1.63(\mathrm{~s}, 9 \mathrm{H}), 1.37(\mathrm{~s}, 9 \mathrm{H}) .{ }^{13} \mathrm{C}$ NMR (101 MHz, $\mathrm{CDCl}_{3}$ ) $\delta 166.7,149.9,148.6,138.4,131.3,130.3,126.0,125.5,123.5,116.9$, 95.6, 85.1, 84.6, 62.7, 32.8, 29.5, 28.0, 27.5. HRMS (ESI): calcd for $\mathrm{C}_{21} \mathrm{H}_{27} \mathrm{NO}_{7} \mathrm{NaClBr}[\mathrm{M}+\mathrm{Na}]^{+}$542.0557; found 542.0531. 7-(tert-butyl) 8-ethyl 3-bromo-8-((tert-butoxycarbonyl)oxy)-7azabicicyclo[4.2.0]octa-1,3,5-triene-7,8-dicarboxylate (4cb). Performed on $50 \mathrm{mg}$ of $3 \mathrm{cb} .39 \mathrm{mg}$ ( $0.0820 \mathrm{mmol}), 61 \%$ yield. FC performed with a mixture of Hexane/Ethyl Acetate as eluant in gradient from 6o:1 to 20:1. ${ }^{1} \mathrm{H}$ NMR $\left(400 \mathrm{MHz}, \mathrm{CDCl}_{3}\right) \delta$ $7.79(\mathrm{~d}, J=8.6 \mathrm{~Hz}, 1 \mathrm{H}), 7.57-7.5 \mathrm{O}(\mathrm{m}, 2 \mathrm{H}), 4.10-4.02(\mathrm{~m}, 2 \mathrm{H})$, $1.63(\mathrm{~s}, 9 \mathrm{H}), 1.37(\mathrm{~s}, 9 \mathrm{H}), 1.22(\mathrm{t}, J=7.1 \mathrm{~Hz}, 3 \mathrm{H}) .{ }^{13} \mathrm{C}$ NMR (101 $\left.\mathrm{MHz}, \mathrm{CDCl}_{3}\right) \delta 167.0,150.3,149.0,139.3134 .4$, 127.0, 126.6, 118.o, 117.6, 96.2, 85.4, 84.7, 61.2, 28.4, 27.8, 15.4. HRMS (ESI): calcd for $\mathrm{C}_{20} \mathrm{H}_{26} \mathrm{NO}_{7} \mathrm{NaBr}[\mathrm{M}+\mathrm{Na}]^{+} 494.0790$; found 494.0788 . 7-(tert-butyl) 8-ethyl 8-((tert-butoxycarbonyl)oxy)-3-methyl-7azabicicyclo[4.2.0]octa-1,3,5-triene-7,8-dicarboxylate (4db).
Performed on $108 \mathrm{mg}$ of $3 \mathrm{db} .69 \mathrm{mg}$ (0.17o mmol), $53 \%$ yield. FC performed with a mixture of Hexane/Ethyl Acetate as eluant in gradient from 50:1 to 10:1. ${ }^{1} \mathrm{H}$ NMR $\left(400 \mathrm{MHz}, \mathrm{CDCl}_{3}\right) \delta$ $7.73(\mathrm{~d}, J=8.3 \mathrm{~Hz}, 1 \mathrm{H}), 7.24-7.23(\mathrm{~m}, 1 \mathrm{H}), 7.20-7.18(\mathrm{~m}, 1 \mathrm{H})$, 4.13-3.99 (m, 2H), $2.34(\mathrm{~s}, 3 \mathrm{H}), 1.62(\mathrm{~s}, 9 \mathrm{H}), 1.33(\mathrm{~s}, 9 \mathrm{H}), 1.21(\mathrm{t}$, $\left.J=7.1 \mathrm{~Hz},{ }_{3} \mathrm{H}\right) .{ }^{13} \mathrm{C}$ NMR $\left(101 \mathrm{MHz}, \mathrm{CDCl}_{3}\right) \delta 167.9,150.2,149.2$, 137.8, 134.8, 132.1, 124.9, 124.0, 115.7, 97.0, 84.8, 84.3, 61.0, 28.4, 27.8, 21.3, 15.5. HRMS (ESI): calcd for $\mathrm{C}_{21} \mathrm{H}_{29} \mathrm{NO}_{7} \mathrm{Na}[\mathrm{M}+\mathrm{Na}]^{+}$ 430.1842; found 430.1818 .

7-(tert-butyl) 8-ethyl 8-((tert-butoxycarbonyl)oxy)-3-nitro-7azabicicyclo[4.2.0]octa-1,3,5-triene-7,8-dicarboxylate (4eb). Performed on $64 \mathrm{mg}$ of zeb. $60 \mathrm{mg}$ (o.137 mmol), $72 \%$ yield. FC performed with a mixture of Hexane/Ethyl Acetate as eluant in gradient from 50:1 to 15:1. ${ }^{1} \mathrm{H} \mathrm{NMR}\left(400 \mathrm{MHz}, \mathrm{CDCl}_{3}\right) \delta$ $8.36-8.30(\mathrm{~m}, 2 \mathrm{H}), 8.09(\mathrm{dd}, J=8.9,0.5 \mathrm{~Hz}, 1 \mathrm{H}), 4.10(\mathrm{q}, J=7.1$ $\mathrm{Hz}, 2 \mathrm{H}), 1.65(\mathrm{~s}, 9 \mathrm{H}), 1.38(\mathrm{~s}, 9 \mathrm{H}), 1.23(\mathrm{t}, J=7.1 \mathrm{~Hz}, 3 \mathrm{H}) .{ }^{13 \mathrm{C}}$ NMR (101 MHz, $\left.\mathrm{CDCl}_{3}\right) \delta 166.7,150.6,148.7,145.3,145.0,127.6$, 126.4, 119.3, 116.2, 95.6, 86.2, 85.1, 61.5, 28.4, 27.8, 15.4. HRMS (ESI): calcd for $\mathrm{C}_{20} \mathrm{H}_{26} \mathrm{~N}_{2} \mathrm{O}_{9} \mathrm{Na}[\mathrm{M}+\mathrm{Na}]^{+} 461.1536$; found 461.1519.

Tert-butyl 8-((tert-butoxycarbonyl)(2-methoxy-2-oxoethyl)carbamoyl)-8-((tert-butoxycarbonyl)oxy)-7-azabicicyclo[4.2.0]octa-1,3,5-triene-7,8-dicarboxylate (4ak). Performed on $110 \mathrm{mg}$ of zak. $130 \mathrm{mg}(0.243 \mathrm{mmol}), 74 \%$ yield. FC performed with a mixture of Hexane/Ethyl Acetate as eluant in gradient from 30:1 to 5:1. ${ }^{1} \mathrm{H}$ NMR $\left(400 \mathrm{MHz}, \mathrm{CDCl}_{3}\right) \delta 7.86(\mathrm{~d}$, $\mathrm{J}=8.2 \mathrm{~Hz}, 1 \mathrm{H}), 7.73(\mathrm{~d}, \mathrm{~J}=7.4 \mathrm{~Hz}, 1 \mathrm{H}), 7.38(\mathrm{td}, \mathrm{J}=8.1,1.3 \mathrm{~Hz}$, $1 \mathrm{H}), 7.16(\mathrm{t}, \mathrm{J}=7.5 \mathrm{~Hz}, 1 \mathrm{H}), 4.46(\mathrm{~d}, \mathrm{~J}=17.9 \mathrm{~Hz}, 2 \mathrm{H}), 3.77(\mathrm{~s}$, $3 \mathrm{H}), 1.61(\mathrm{~s}, 9 \mathrm{H}), 1.26(\mathrm{~s}, 9 \mathrm{H}), 1.11(\mathrm{~s}, 9 \mathrm{H}) .13 \mathrm{C}$ NMR (101 MHz, $\left.\mathrm{CDCl}_{3}\right) \delta 170.9,169.6,152.5$, 149.0, 148.0, 141.8, 131.0, 125.2, 124.6, $124.2,114.9,85.1,84.5,84.1,82.8,52.0,46.0$, 28.0, 27.6, 27.3. HRMS (ESI): calcd for $\mathrm{C}_{26} \mathrm{H}_{36} \mathrm{~N}_{2} \mathrm{O}_{10} \mathrm{~K}[\mathrm{M}+\mathrm{K}]^{+} 575.2007$; found 575.1999.

Tert-butyl 8-((tert-butoxycarbonyl)((S)-1-methoxy-1-oxo-3phenylpropan-2-yl)carbamoyl)-8-((tert-butoxycarbonyl)oxy)7-azabicicyclo[4-2.0]octa-1,3,5-triene-7-carboxylate (4al). Performed on $38 \mathrm{mg}$ of $3 \mathrm{al} .35 \mathrm{mg}$ (0.0558 mmol), $79 \%$ yield. FC performed with a mixture of Hexane/Ethyl Acetate as eluant in gradient from 40:1 to 5:1. ${ }^{1} \mathrm{H} \mathrm{NMR}\left(400 \mathrm{MHz}, \mathrm{CDCl}_{3}\right) \delta 7.90$ $(\mathrm{d}, \mathrm{J}=8.2 \mathrm{~Hz}, 1 \mathrm{H}), 7.54(\mathrm{~d}, \mathrm{~J}=7.3 \mathrm{~Hz}, 2 \mathrm{H}), 7.49-7.32(\mathrm{~m}, 3 \mathrm{H})$, $7.25-7.16(\mathrm{~m}, 2 \mathrm{H}), 7.13(\mathrm{t}, \mathrm{J}=7.4 \mathrm{~Hz}, 1 \mathrm{H}), 4.83(\mathrm{dd}, \mathrm{J}=8.8,2.9$ $\mathrm{Hz}, \mathrm{H}), 3.74-3.65(\mathrm{~m}, \mathrm{lH}), 3.63(\mathrm{~s}, 3 \mathrm{H}), 3.21(\mathrm{dd}, \mathrm{J}=13.7,2.9$ $\mathrm{Hz}, 1 \mathrm{H}), 1.63(\mathrm{~s}, \mathrm{~J}=2.2 \mathrm{~Hz}, 9 \mathrm{H}), 1.33(\mathrm{~s}, 9 \mathrm{H}), 1.24(\mathrm{~s}, 9 \mathrm{H}) .{ }^{13} \mathrm{C}$ NMR (101 MHz, $\left.\mathrm{CDCl}_{3}\right) \delta$ 171.5, 169.2, 152.1, 149.1, 147.9, 141.8, 139.5, 139.4, 134.6, 130.9, 130.0, 128.1, 126.1, 124.2, 123.7, 114.9, 86.1, 84.3, 84.0, 83.0, 59.7, 52.0, 38.9, 28.1, 27.7, 27.3. Tabulation referred to the major diastereoisomer. HRMS (ESI): calcd for $\mathrm{C}_{33} \mathrm{H}_{42} \mathrm{~N}_{2} \mathrm{O}_{10} \mathrm{~K}[\mathrm{M}+\mathrm{K}]^{+} 665.2477$; found 665.2472 .

Tert-butyl 8-((tert-butoxycarbonyl)((S)-1-methoxy-1-3-methyl1-oxobutan-2-yl)carbamoyl)-8-((tert-butoxycarbonyl)oxy)-7azabicicyclo[4-2.0]octa-1,3,5-triene-7-carboxylate (4am). Performed on $90 \mathrm{mg}$ of $3 \mathrm{am}$. $111 \mathrm{mg}$ ( $0.192 \mathrm{mmol}), 81 \%$ yield. FC performed with a mixture of Hexane/Ethyl Acetate as eluant in gradient from 30:1 to $5: 1 .{ }^{1} \mathrm{H}$ NMR $\left(400 \mathrm{MHz}, \mathrm{CDCl}_{3}\right) \delta 7.91$ $(\mathrm{d}, \mathrm{J}=8.2 \mathrm{~Hz}, \mathrm{lH}), 7.56(\mathrm{dd}, \mathrm{J}=7.6,0.8 \mathrm{~Hz}, 1 \mathrm{H}), 7.39(\mathrm{td}, \mathrm{J}=8.1$, $1.3 \mathrm{~Hz}, 1 \mathrm{H}), 7.14(\mathrm{td}, \mathrm{J}=7.6,0.7 \mathrm{~Hz}, 1 \mathrm{H}), 4.32(\mathrm{~d}, \mathrm{~J}=8.0 \mathrm{~Hz}, 1 \mathrm{H})$, $3.65(\mathrm{~s}, 3 \mathrm{H}), 2.66-2.55(\mathrm{~m}, \mathrm{lH}), 1.62(\mathrm{~s}, 9 \mathrm{H}), 1.27(\mathrm{~s}, 9 \mathrm{H}), 1.21$ (s, $9 \mathrm{H}), 1.17-1.11(\mathrm{~m}, 6 \mathrm{H}) .{ }^{13} \mathrm{C} \mathrm{NMR}\left(101 \mathrm{MHz}, \mathrm{CDCl}_{3}\right) \delta$ 172.1, 169.0, 152.3, 149.7, 148.3, 142.2, 131.2, 124.5, 124.3, 124.1, 115.4, $85.6,84.7,84.1,83.0,62.5,52.0,30.0,28.5,28.1,27.7,22.5,19.9$. 
HRMS (ESI): calcd for $\mathrm{C}_{29} \mathrm{H}_{42} \mathrm{~N}_{2} \mathrm{O}_{10} \mathrm{Na}[\mathrm{M}+\mathrm{Na}]+601.2737$; found 601.2748 .

Ethyl 2-(2,2-((diBoc)amino)-5-methylphenyl)-2-oxoacetate (5db). $46 \mathrm{mg}$ (0.113 mmol), $35 \%$ yield. FC performed with a mixture of Hexane/Ethyl Acetate as eluant in gradient from 50:1 to 10:1. ${ }^{1} \mathrm{H}$ NMR (400 $\left.\mathrm{MHz}, \mathrm{CDCl}_{3}\right) \delta_{7.62}\left(\mathrm{~d}, J=1.7 \mathrm{~Hz},{ }_{1} \mathrm{H}\right)$, $7.39(\mathrm{dd}, J=8.1,1.6 \mathrm{~Hz}, 1 \mathrm{H}), 7.10(\mathrm{~d}, J=8.1 \mathrm{~Hz}, 1 \mathrm{H}), 4.39(\mathrm{q}, J=$ $7.2 \mathrm{~Hz}, 2 \mathrm{H}), 2.40(\mathrm{~s}, 3 \mathrm{H}), 1.39(\mathrm{~m}, 3 \mathrm{H}), 1.36(\mathrm{~s}, 18 \mathrm{H}) .{ }^{13} \mathrm{C}$ NMR $\left(101 \mathrm{MHz}, \mathrm{CDCl}_{3}\right) \delta 186.9,164.3,150.8,138.4,137.1,135.1,131.5$, 131.3, 130.1, 83.5, 62.9, 28.0, 21.3, 14.3. HRMS (ESI): calcd for $\mathrm{C}_{21} \mathrm{H}_{29} \mathrm{NO}_{7} \mathrm{Na}[\mathrm{M}+\mathrm{Na}]+{ }_{4} 430.1842$; found 430.1855 .

\section{Synthetic procedures for compounds 6-9.}

Ethyl 2-(2-((4-methylphenyl)sulfonamido)phenyl)-2-oxoacetate (6). $1 \mathrm{~g}$ of isatin $(6.8 \mathrm{mmol}, 1$ equiv) was dissolved in $14 \mathrm{~mL}$ of dichloromethane and the solution was cooled to ${ }^{\circ}{ }^{\circ} \mathrm{C}$ with ice bath. Then $1.94 \mathrm{mg}$ of $\mathrm{p}$-Toluenesulfonyl chloride (10.2 mmol, 1.5 equiv) were added to the solution and subsequently $2.84 \mathrm{~mL}$ of $\mathrm{Et}_{3} \mathrm{~N}$ (20.4 mmol, 3 equiv) were added dropwise. The solution was stirred at room temperature. After $2 \mathrm{~h}, 30 \mathrm{~mL}$ of ethanol ( $0.51 \mathrm{~mol}, 75$ equiv) were added and the mixture was stirred for $12 \mathrm{~h}$. The crude product was purified with flash silica chromatography using a mixture of petroleum ether/ethyl acetate (10:1 to 1:1), affording 6 as an ocher solid. $1.30 \mathrm{~g}$ (3.74 mmol), $55 \%$ yield. ${ }^{1} \mathrm{H}$ NMR (40o $\mathrm{MHz}, \mathrm{CDCl}_{3}$ ) $\delta$ $10.75(\mathrm{~s}, 1 \mathrm{H}), 7.77(\mathrm{~d}, \mathrm{~J}=8.2 \mathrm{~Hz}, 2 \mathrm{H}), 7.72(\mathrm{~d}, \mathrm{~J}=8.5 \mathrm{~Hz}, 1 \mathrm{H})$, $7.64-7.60(\mathrm{~m}, 1 \mathrm{H}), 7.53(\mathrm{dd}, \mathrm{J}=8.2,7.7 \mathrm{~Hz}, 1 \mathrm{H}), 7.25(\mathrm{~m}, 2 \mathrm{H})$, $7.08(\mathrm{t}, \mathrm{J}=7.7 \mathrm{~Hz}, 1 \mathrm{H}), 4.43(\mathrm{q}, \mathrm{J}=7.1 \mathrm{~Hz}, 2 \mathrm{H}), 2.37\left(\mathrm{~s},{ }_{3} \mathrm{H}\right), 1.4 \mathrm{O}$ $\left(\mathrm{t}, \mathrm{J}=7.1 \mathrm{~Hz},{ }_{3} \mathrm{H}\right) .{ }^{13} \mathrm{C}$ NMR (101 $\left.\mathrm{MHz}, \mathrm{CDCl}_{3}\right) \delta 190.3,163.4$, 144.7, 142.1, 137.0, 136.5, 134.2, 130.2, 127.7, 123.0, 118.9, 117.9, 63.1, 21.9, 14.4. HRMS (ESI): calcd for $\mathrm{C}_{17} \mathrm{H}_{17} \mathrm{NO}_{5} \mathrm{NaS}[\mathrm{M}+\mathrm{Na}]^{+}$ 370.0725; found 370.0723 .

Ethyl 2-(2-(((benzyloxy) carbonyl)amino)phenyl)-2-oxoacetate (7). $1.768 \mathrm{~g}$ of $\mathrm{N}-\mathrm{CBz}$-isatin (6.29 mmol, 1 equiv) were suspended in $\mathrm{EtOH}(18 \mathrm{~mL}, 314,5 \mathrm{mmol}, 50$ equiv) then $0.334 \mathrm{~mL}$ of $\mathrm{Et}_{3} \mathrm{~N}(2.51 \mathrm{mmol}, 40 \mathrm{~mol} \%)$ was added. The reaction was stirred at room temperature for $24 \mathrm{~h}$, then the crude product was adsorbed on silica and purified with flash silica chromatography using a mixture of hexane and ethyl acetate as eluant (10:1 to 5:1), affording 7 as a yellow oil. $605 \mathrm{mg}(1.85 \mathrm{mmol}), 29$ \% yield. ${ }^{1} \mathrm{H}$ NMR (300 $\left.\mathrm{MHz}, \mathrm{CDCl}_{3}\right) \delta 10.68(\mathrm{~s}, 1 \mathrm{H}), 8.56(\mathrm{~d}, \mathrm{~J}=$ $8.5 \mathrm{~Hz}, 1 \mathrm{H}), 7.73-7.57(\mathrm{~m}, 2 \mathrm{H}), 7.48-7.31(\mathrm{~m}, 5 \mathrm{H}), 7.10(\mathrm{dd}, \mathrm{J}$ $=11.8,4.3 \mathrm{~Hz}, 1 \mathrm{H}), 5.24(\mathrm{~s}, 2 \mathrm{H}), 4.46(\mathrm{q}, \mathrm{J}=7.2 \mathrm{~Hz}, 2 \mathrm{H}), 1.42(\mathrm{t}$, $\left.\mathrm{J}=7.1 \mathrm{~Hz},{ }_{3} \mathrm{H}\right) .{ }^{13} \mathrm{C}$ NMR $\left(75 \mathrm{MHz} \mathrm{CDCl}_{3}\right) \delta 190.4,163.9,153.6$, $143.3,137.2$, 136.1, 133.8, 128.9, 128.6, 128.5, 122.1, 119.5, 117.1, 67.5, 62.8, 14.4. HRMS (ESI): calcd for $\mathrm{C}_{18} \mathrm{H}_{17} \mathrm{NO}_{5} \mathrm{Na}[\mathrm{M}+\mathrm{Na}]^{+}$ 350.1004; found 350.0994 .

Tert-butyl (2-ethoxy-3-oxo-1-tosylindolin-2-yl)carbonate (8). $100 \mathrm{mg}$ of 6 ( $0.28 \mathrm{mmol}, 1$ equiv) were dissolved in $0.90 \mathrm{~mL}$ of dichloromethane. After 10 minutes $189 \mathrm{mg}$ of $\mathrm{Boc}_{2} \mathrm{O}$ (o.87 mmol, 3.1 equiv) and $91 \mathrm{mg}$ of quinine ( $0.28 \mathrm{mmol}, 1$ equiv) were added and the mixture was stirred at room temperature for 4 days. The crude was purified with flash silica chromatography using as eluant a mixture of petroleum ether and ethyl acetate (10:1 to 8:1). $6 \mathrm{mg}$ (0.0134 mmol), $5 \%$ yield. ${ }^{1} \mathrm{H}$ NMR $\left(400 \mathrm{MHz}, \mathrm{CDCl}_{3}\right) \delta 7.98(\mathrm{~d}, \mathrm{~J}=8.4 \mathrm{~Hz}, 2 \mathrm{H}), 7.77(\mathrm{~d}, \mathrm{~J}=8.5 \mathrm{~Hz}$, $1 \mathrm{H}), 7.63(\mathrm{dd}, \mathrm{J}=7.6,0.8 \mathrm{~Hz}, \mathrm{lH}), 7.58(\mathrm{ddd}, \mathrm{J}=8.7,7.4,1.5 \mathrm{~Hz}$, $1 \mathrm{H}), 7.22(\mathrm{~d}, \mathrm{~J}=8.1 \mathrm{~Hz}, 2 \mathrm{H}), 7.09(\mathrm{td}, \mathrm{J}=7.5,0.7 \mathrm{~Hz}, 1 \mathrm{H}), 3.88$ $(\mathrm{q}, \mathrm{J}=7.1 \mathrm{~Hz}, 2 \mathrm{H}), 2.37(\mathrm{~s}, 3 \mathrm{H}), 1.38(\mathrm{~s}, 9 \mathrm{H}), 1.20(\mathrm{t}, \mathrm{J}=7.1 \mathrm{~Hz}$, $\left.{ }_{3} \mathrm{H}\right) .{ }^{13} \mathrm{C} \mathrm{NMR}\left(75 \mathrm{MHz} \mathrm{CDCl}_{3}\right.$ ) $\delta$ 193.2, 149.8, 144.1, 137.8, 136.9, 129.8, 129.1, 128.5, 124.9, 123.4, 120.0, 114.9, 106.8, 79.6, 6o.o,
29.9, 21.5, 14.8. HRMS (ESI): calcd for $\mathrm{C}_{17} \mathrm{H}_{17} \mathrm{NO}_{5} \mathrm{NaS}[\mathrm{M}-$ $\left.\left(\mathrm{CH}_{3}\right)_{3} \mathrm{COC}=\mathrm{O}+\mathrm{H}+\mathrm{Na}\right]^{+} 370.0725$; found 370.0708 .

Benzyl 2-((tert-butyldimethylsilyl)oxy)-2-ethoxy-3-oxoindoline-1-carboxylate (9). $84 \mathrm{mg}$ of 7 (0.257 mmol, 1 equiv) and 129 mg of TBDMSOTf ( $t$-butildimethylsilyl trifluoromethanesulphonate, $0.488 \mathrm{mmol}, 1.9$ equiv) were loaded in a two-neck round flask under a flow of argon, then dissolved in $2.17 \mathrm{~mL}$ of anhydrous dichloromethane. After this $66 \mu \mathrm{L}$ of 2,6-dimethylpyridine ( $0.565 \mathrm{mmol}, 2.2$ equiv) were added and the reaction stirred at room temperature for $18 \mathrm{~h}$. The crude was then diluted with $10 \mathrm{~mL}$ of $\mathrm{Et}_{2} \mathrm{O}$, washed with brine $(3 \times 10 \mathrm{~mL})$ and the aqueous layers extracted with $\mathrm{Et}_{2} \mathrm{O}(3 \times 15 \mathrm{~mL})$. The organic fractions were reunited, dried over $\mathrm{Na}_{2} \mathrm{SO}_{4}$, evaporated at reduced pressure and purified with flash silica chromatography using as eluant a mixture of hexane and ethyl acetate (20:1 to 8:1). $49 \mathrm{mg}$ (0.111 mmol), $43 \%$ yield. ${ }^{~} \mathrm{H}$ NMR (300 MHz, $\left.\mathrm{CDCl}_{3}\right) \delta 8.18(\mathrm{~d}, \mathrm{~J}=8.4 \mathrm{~Hz}, 1 \mathrm{H}), 7.71-7.60(\mathrm{~m}, 2 \mathrm{H}), 7.47(\mathrm{dd}$, $\mathrm{J}=7.7,1.4 \mathrm{~Hz}, 2 \mathrm{H}), 7.37(\mathrm{ddd}, \mathrm{J}=12.7,5.5,3.4 \mathrm{~Hz}, 3 \mathrm{H}), 7.14(\mathrm{t}, \mathrm{J}$ $=7.5 \mathrm{~Hz}, 1 \mathrm{H}), 5.53(\mathrm{~d}, \mathrm{~J}=12.4 \mathrm{~Hz}, \mathrm{lH}), 5.16(\mathrm{~d}, \mathrm{~J}=12.3 \mathrm{~Hz}, 1 \mathrm{H})$, $3.53-3.44(\mathrm{~m}, 2 \mathrm{H}), 1.10\left(\mathrm{t}, \mathrm{J}=7.0 \mathrm{~Hz},{ }_{3} \mathrm{H}\right), 0.83(\mathrm{~s}, 9 \mathrm{H}), 0.13(\mathrm{~s}$, $3 \mathrm{H})$, o.10 (s, $3 \mathrm{H}) .{ }^{13} \mathrm{C}$ NMR $\left(75 \mathrm{MHz} \mathrm{CDCl}_{3}\right) \delta$ 194.5, 152.2, 151.4, $138.5,136.2,134.4,128.8,128.6,124.7,123.7,120.1,116.8,103.2$, $67.6,60.2,25.8,18.4,15.2,-2.9,-3.3$. HRMS (ESI): calcd for $\mathrm{C}_{24} \mathrm{H}_{31} \mathrm{NO}_{5} \mathrm{NaSi}[\mathrm{M}+\mathrm{Na}]^{+} 464.1869$; found 464.1866 .

\section{ASSOCIATED CONTENT}

\section{Supporting Information}

The Supporting Information is available free of charge on the ACS Publications website. $1 \mathrm{D}$ and $2 \mathrm{D}-\mathrm{NMR}$ spectra $\left({ }^{1} \mathrm{H}\right.$ and $\left.{ }^{13} \mathrm{C}\right)$. IR spectra. Details about the DOE. Coordinates and Energies of the DFT calculations.

\section{AUTHOR INFORMATION}

\section{Corresponding Author}

*E-mail: riccardo.salvio@uniroma1.it, marco.bella@uniroma1.it.

\section{ORCID}

Riccardo Salvio: oooo-0003-0398-8408

Marco Bella: oooo-0003-2223-6025

Notes The authors declare no competing financial interest.

\section{ACKNOWLEDGMENT}

Authors wish to thank Sapienza Università di Roma for financial support through "Progetti di Ateneo" 2016 and 2017. Authors are indebted to Prof. Luigi Mandolini for several useful discussions. Giovanni Misantoni, Arianna Sisto and Marco Baldazzi are acknowledged for technical assistance in the laboratory. Giorgio Capocasa is acknowledged for his assistance in the mass spectrometry analysis. 


\section{-REFERENCES}

(1) Fleming, J. J.; McReynolds, M. D.; Du Bois, J. (+)-Saxitoxin: A First and Second Generation Stereoselective Synthesis. J. Am. Chem. Soc., 2007, 129, 9964-9975.

(2) Iwasawa, T.; Hooley, R. J.; Rebek, J. Stabilization of Labile Carbonyl Addition Intermediates by a Synthetic Receptor. Science, 2007, 317, 493-496.

(3) Kawamichi, T.; Haneda, T.; Kawano, M.; Fujita, M. X-ray observation of a transient hemiaminal trapped in a porous network. Nature, 2009, 461, 633-635.

(4) Zhou, Y.; Yuan, Y.; You, L.; Anslyn, E. V. Dynamic AminalBased TPA Ligands. Chem. Eur. J., 2015, 21, 8207-8213.

(5) a) Puglisi, A.; Giustini, C.; Ricucci, A.; Perotti, E.; Massaro, L.; Morra, D.; Ciucci, F.; Zucchet, A.; Antenucci, A.; Moliterno, M.; Placidi, S.; Sciubba, F.; Galantini, L.; Salvio, R.; Bella, M. Synthesis of Benzofuranones via Malonates Desymmetrization: Yield Increase by the Portion-wise Addition of Quinones. Chem. Eur. J., 2018, 24, 6941-6945. b) Moliterno, M., Cari, R.; Puglisi, A.; Antenucci, A.; Sperandio, C.; Moretti, E.; Di Sabato, A.; Salvio, R.; Bella, M. Quinine-Catalyzed Asymmetric Synthesis of 2,2'Binaphthol-Type Biaryls under Mild Reaction Conditions. Angew. Chem. Int. Ed., 2016, 55, 6525-6529. c) Salvio, R.; Moliterno, M.; Caramelli, D.; Pisciottani, L.; Antenucci, A.; D'Amico, M.; Bella, M. Kinetic resolution of phosphoric diester by Cinchona alkaloid derivatives provided with a guanidinium unit. Catal. Sci. Technol., 2016, 6, 2280-2288. d) Salvio, R.; Massaro, L.; Puglisi, A.; Angelini, L.; Antenucci, A.; Placidi, S.; Sciubba, F.; Galantini, L.; Bella, M. Organocatalysis and catalyst aggregation: a study using the asymmetric synthesis of benzofuranones as a test reaction Org. Biomol. Chem. 2018, 16, 7041-7049.

(6) Sadana, A. K.; Saini, R. K.; Billups, W. E. Cyclobutarenes and Related Compounds. Chem. Rev., 2003, 103, 1539-1602.

(7) Brandi, A.; Cicchi, S.; Cordero, F. M. Novel Syntheses of Azetidines and Azetidinones. Chem. Rev., 2008, 108, 3988-4035.

(8) Rocaboy, R.; Dailler, D.; Zellweger, F.; Neuburger, M.; Salom, C.; Clot, E.; Baudoin, O. Domino Pd ${ }^{\circ}-$ Catalyzed C( $\left.\mathrm{sp}^{3}\right)-\mathrm{H}$ Arylation/Electrocyclic Reactions via Benzazetidine Intermediates. Angew. Chem. Int. Ed., 2018, 57, 12131 -12135.

(9) He, G.; Lu, G.; Guo, Z.; Liu, P.; Chen, G. Benzazetidine synthesis via palladium-catalysed intramolecular $\mathrm{C}-\mathrm{H}$ amination. Nat. Chem.,2016, 8, 1131 - 1136.

(10) Didier, D.; Baumann, A. N.; Eisold, M. Unsaturated fourmembered N-heterocycles: From synthesis to applications. Tetrahedron Lett., 2018, 59, 3975-3987.

(11) Kobayashi, K.; Miyamoto, K.; Morikawa, O.; Konishi, H. Synthesis of Benzazetine Derivatives by Intramolecular Iodoamination of o-(Acylamino)styrene Derivatives. Bull. Chem. Soc. Jpn. 2005, 78, 886-889.

(12) Okuma, K.; Takeshita, I.; Yasuda, T.; Shioji, K. Regioselective Synthesis of Benzazetines and Indoles from Alkenylanilides and Dimethyl(methylthio)sulfonium Trifluoromethanesulfonate. Chem. Lett. 2006, 35, 1122-1123.

(13) a) Lancaster, M.; Smith, D. J. H. Preparation and some reactions of benzoazetidines. J. Chem. Soc. Chem. Commun. 1980, 471472; b) Beak, P.; Selling, G. W. Displacements at the Nitrogen of Lithioalkoxylamides by Organometallic

Reagents. J. Org. Chem. 1989, 54, 5574-558o.

(14) Wojciechowski, K. Aza-ortho-xylylenes in Organic Synthesis. Eur. J. Org. Chem. 2001, 3587-3605.
(15) Dailler, D.; Rocaboy, R.; Baudoin, O. Synthesis of $\beta$-Lactams by Palladium(o)-Catalyzed $\mathrm{C}\left(\mathrm{sp}^{3}\right)-\mathrm{H}$ Carbamoylation Angew. Chem. Int. Ed. 2017, 56, 7218-7222.

(16) a) Chaumontet, M.; Piccardi, R.; Audic, N.; Hitce, J.; Peglion, J. L.; Clot, E.; Baudoin, O. Synthesis of Benzocyclobutenes by Palladium-Catalyzed C-H Activation of Methyl Groups: Method and Mechanistic Study. J. Am. Chem. Soc. 2oo8, 130, 15157-15166; b) Baudoin, O.; Herrbach, A.; Gueritte, F. The Palladium-Catalyzed C-H Activation of Benzylic gem-Dialkyl Groups. Angew. Chem. Int. Ed. 2003, 42, 5736-5740.

(17) Baudoin, O. Ring Construction by Palladium(o)-Catalyzed C(sp3)-H Activation. Acc. Chem. Res. 2017, 50, 1114-1123.

(18) a) Li, G.; Liang, T.; Wojtas, L.; Antilla, J. C. An Asymmetric Diels-Alder Reaction Catalyzed by Chiral Phosphate Magnesium Complexes: Highly Enantioselective Synthesis of Chiral Spirooxindoles. Angew. Chem. Int. Ed. 2013, 125, 4726-4730; b) Yamagishi, M.; Yamada, Y.; Ozaki, K.-i.; Tani, J.; Mamoru, S. Quinazolin2ones Having a Spirohydantoin Ring. II. Synthesis of Several Spiro[imidazolidine-4, 4'(1'H)-quinazoline]-2, 2', 5(3'H)-triones via 5-Hydroxyhydantoin Derivatives. Chem. Pharm. Bull. 1991, 39, 626-629; c) Noole, A.; Sucman, N. S.; Kabeshov, M. A.; Kanger, T.; Macaev, F. Z.; Malkov, A. V. Highly Enantio- and Diastereoselective Generation of Two Quaternary Centers in Spirocyclopropanation of Oxindole Derivatives. Chem. Eur. J. 2012, 18, 14929-14933; d) Tan, B.; Candeias, N. R.; Barbas 3rd, C. F. Core-Structure-Motivated Design of a Phosphine-Catalyzed [3 + 2] Cycloaddition Reaction: Enantioselective Syntheses of Spirocyclopenteneoxindoles. J. Am. Chem. Soc. 2011, 133, 4672-4675.

(19) a) Liu, Y. L.; Zhou, J. Organocatalytic asymmetric cyanation of isatin derived N-Boc ketoimines. Chem. Comm., 2013, 49, 44214423; b) Gardena, S. J.; Skakle, J. M. S. Isatin derivatives are reactive electrophilic components for the Baylis-Hillman reaction. Tetrahedron Lett., 2002, 43, 1969-1972.

(20) Chahal, V.; Nirwan, S.; Kakkar, R. Isatin and its derivatives: a survey of recent syntheses, reactions, and applications. Med. Chem. Commun. 2019, DOI: 10.1039/C1038MDo0585K.

(21) Baldwin, J. E. Rules for ring closure. J. Chem. Soc., Chem. Commun. 1976, 734-736.

(22) Anslyn, E. V.; Dougherty, D. A. Modern Physical Organic Chemistry 2oo6. University Science Books. Sausalito, California.

(23) Vakulya, B.; Varga, S.; Csámpai, A.; Soós, T. Highly Enantioselective Conjugate Addition of Nitromethane to Chalcones Using Bifunctional Cinchona Organocatalysts. Org. Lett., 2005, 7, 1967-1969.

(24) Basel, Y.; Hassner, A. Di-tert-butyl Dicarbonate and 4-(Dimethylamino)pyridine Revisited. Their Reactions with Amines and Alcohols. J. Org. Chem., 20oo, 65, 6368-638o.

(25) For recent examples of DoE applied to organic synthesis see: a) Renzi, P.; Kronig, C.; Carlone, A.; Eroksuz, S.; Berkessel, A.; Bella, M. Kinetic Resolution of Oxazinones: Rational Exploration of Chemical Space through the Design of Experiments. Chem. Eur. J., 2014, 20, 11768-11775. b) García-Cabeza, A. L.; Marín-Barrios, R.; Azarken, R.; Moreno-Dorado, F. J.; Ortega, M. J.; Vidal, H.; Gatica, J. M.; Massanet, G. M.; Guerra, F. M. DoE (Design of Experiments) Assisted Allylic Hydroxylation of Enones Catalysed by a CopperAluminium Mixed Oxide. Eur. J. Org. Chem. 2013, 8307-8314.

(26) Frisch, M. J. et al. Gaussian o9, Revision D.o1; Gaussian,Inc.: Wallingford CT, 2009.

(27) Wheeler, S. E.; Houk, K. N.; Schleyer, P. v. R.; Allen, W. D. J. A Hierarchy of Homodesmotic Reactions for Thermochemistry. J. Am. Chem. Soc. 2009, 131, 2547-256o. 
(28) Smith, S. A.; Hand, K. E.; Love, M. L.; Hill, G.; Magers, D. H. Conventional strain energies of azetidine and phosphetane: Can density functional theory yield reliable results?. J. Comput. Chem.2013, 34, 558-565.

\section{TOC GRAPHIC}

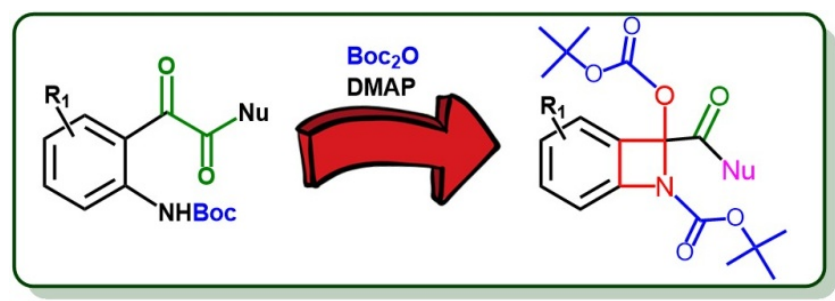

